

\title{
A Comparative Review of a Dozen National Energy Plans: Focus on Renewable and Efficient Energy
}

\author{
Jeffrey Logan and Ted L. James
}

Prepared under Task No. SAO7.9C50

National Renewable Energy Laboratory 1617 Cole Boulevard, Golden, Colorado 80401-3393 303-275-3000 • www.nrel.gov

NREL is a national laboratory of the U.S. Department of Energy Office of Energy Efficiency and Renewable Energy

Operated by the Alliance for Sustainable Energy, LLC

Technical Report NREL/TP-6A2-45046

March 2009

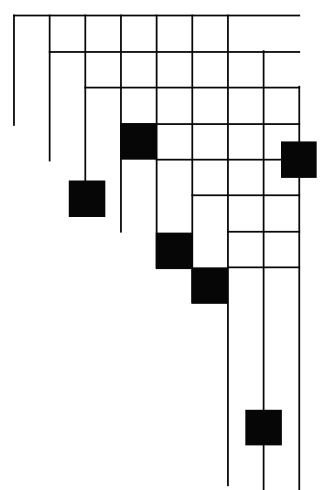




\section{NOTICE}

This report was prepared as an account of work sponsored by an agency of the United States government. Neither the United States government nor any agency thereof, nor any of their employees, makes any warranty, express or implied, or assumes any legal liability or responsibility for the accuracy, completeness, or usefulness of any information, apparatus, product, or process disclosed, or represents that its use would not infringe privately owned rights. Reference herein to any specific commercial product, process, or service by trade name, trademark, manufacturer, or otherwise does not necessarily constitute or imply its endorsement, recommendation, or favoring by the United States government or any agency thereof. The views and opinions of authors expressed herein do not necessarily state or reflect those of the United States government or any agency thereof.

Available electronically at http://www.osti.gov/bridge

Available for a processing fee to U.S. Department of Energy and its contractors, in paper, from:

U.S. Department of Energy

Office of Scientific and Technical Information

P.O. Box 62

Oak Ridge, TN 37831-0062

phone: 865.576 .8401

fax: 865.576 .5728

email: mailto:reports@adonis.osti.gov

Available for sale to the public, in paper, from:

U.S. Department of Commerce

National Technical Information Service

5285 Port Royal Road

Springfield, VA 22161

phone: 800.553 .6847

fax: 703.605.6900

email: orders@ntis.fedworld.gov

online ordering: http://www.ntis.gov/ordering.htm 


\section{Acknowledgments}

This work was funded by the U.S. Department of Energy's (DOE) Office of Energy Efficiency and Renewable Energy (EERE). The authors are grateful for the guidance and helpful input from Doug Arent, Bill Babiuch, Monisha Shah, and Dan Bilello of the National Renewable Energy Laboratory (NREL); and David Rogers from DOE. We would also like to thank the individuals who reviewed various drafts of this report, including Trevor Houser (Peterson Institute of International Economics), Carla Frisch (DOE), Anne Jakle (Sentech Inc.), Rebecca Garland (American Association for the Advancement of Science - AAAS - Science and Technology Policy Fellow at EERE), Austin Brown (AAAS Science and Technology Policy Fellow at EERE), and Avi Gopstein (AAAS Science and Technology Policy Fellow at EERE). The authors also offer their thanks to Michelle Kubik in the NREL Technical Communications Office for providing editorial support. 


\section{List of Acronyms}

ARPA-E - Advanced Research Project Agency - Energy (analogous to the Defense Advanced Research Projects Agency, DARPA)

CAP - Center for American Progress

CCS - Carbon capture and sequestration (or storage)

CHP - Combined heat and power

$\mathrm{CNG}$ - Compressed natural gas

DOE - Department of Energy

EEI - Edison Electric Institute

EERE - Energy Efficiency and Renewable Energy

EIA - Energy Information Administration (DOE)

EISA - Energy Independence and Security Act of 2007

EPA - Environmental Protection Agency

EPAct 2005 - The Energy Policy Act of 2005

ESCO - Energy service company

FEMP - Federal Energy Management Program

FERC - Federal Energy Regulatory Commission

GHG - Greenhouse gas

GW - Gigawatt (1 billion watts)

HVAC - Heating, ventilation, and air conditioning

IEA - International Energy Agency (Paris)

ITC - Investment tax credit

IGCC - Integrated gasification combined cycle

LCOE - Levelized cost of electricity 


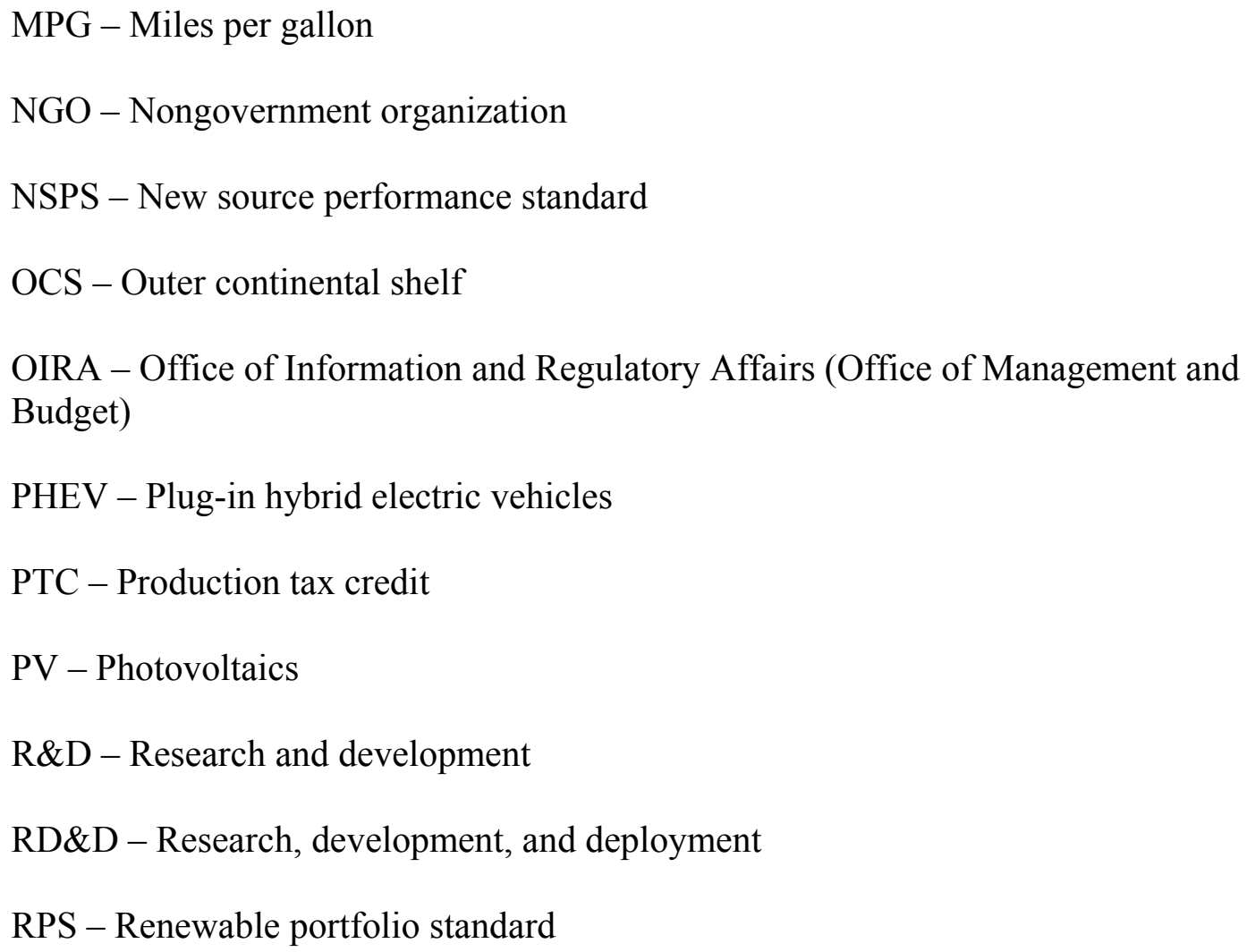




\section{Executive Summary}

Dozens of groups have submitted energy, environmental, and economic recovery plans for consideration by the Obama administration and the $111^{\text {th }}$ Congress. This report provides a comparative analysis of 12 national proposals, focusing especially on energy efficiency (EE) and renewable energy (RE) market and policy issues.

Many of the plans considered here call for transformative change, citing decades of inconsistent, inattentive, or otherwise failed national energy policy. Almost universally, plans call for an expansion of clean energy research and development, EE and RE deployment, and climate change preparedness. But sharp differences also exist regarding domestic drilling, nuclear power, carbon mitigation, and the role of government.

The energy plans place different levels of importance on energy security, environmental protection, and economic revitalization - the "Three Es." Some of these differences are due simply to politics and others to the timing of the unfolding economic crisis. Plans designed to address economic recovery through green jobs are in ascendancy, while those focusing on energy security are receiving less attention due to the collapse in energy prices and demand. Some plans reflect their visions in detailed blueprints of action, while others offer sparse policy direction.

The plans provide hundreds of specific recommendations, some challenging to implement. Doubling wind power output by 2012 - as recently called for by the Obama administration - would likely require repeating the installation of 8 gigawatts $(\mathrm{GW})$ of new wind capacity for each of the next three years. Recent changes in renewable energy incentives in the American Recovery and Reinvestment Act could promote significant new investments, despite the economic slowdown. Other recommendations, such as building 10 carbon capture and sequestration plants, face greater challenges and unknowns.

Evaluating the implementation challenges in most recommendations often depends on policy design details that the plans do not address. One plan, for example, calls for " $100 \%$ clean electricity within 10 years." Such an achievement would require all coaland gas-fired power plants to stop generating before their investment costs have been recovered. How generators would be compensated for their stranded costs is not considered in the plan. Many other recommendations have been proposed including a $25 \%$ renewable portfolio standard (RPS) by 2025, rapid deployment of plug-in hybrid electric vehicles (PHEVs), and various cap-and-trade policies. Additional analysis is required in most areas to evaluate implementation challenges under different policy design assumptions.

Integrating short-term economic recovery with longer-term priorities such as carbon mitigation is possible, but often not without trade-offs. Some short-term measures may contradict longer-term objectives (highway reconstruction and "sustainability"), while overlapping jurisdiction could lead to unintended consequences from other policy interactions (a national RPS combined with cap-and-trade legislation). Evaluating the nuances of these tradeoffs goes beyond the scope of this report. 


\section{Table of Contents}

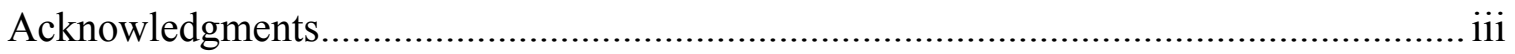

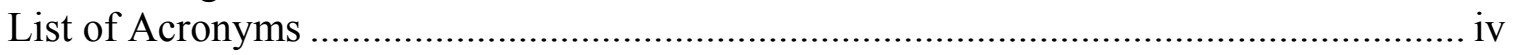

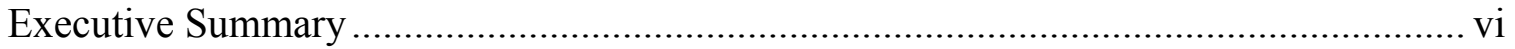

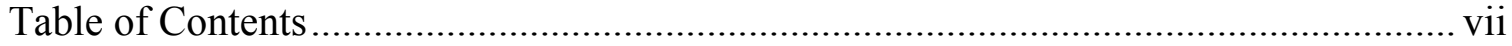

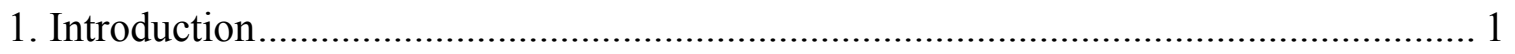

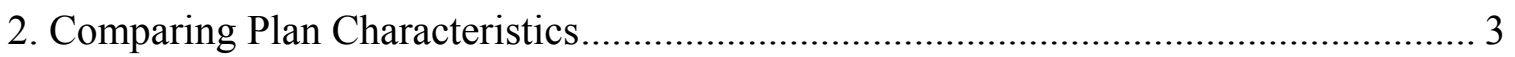

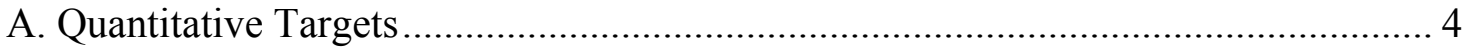

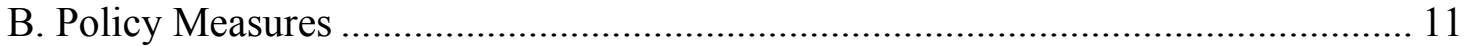

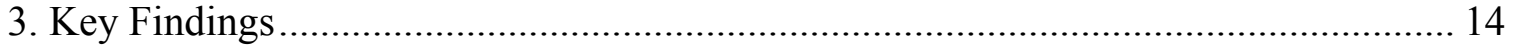

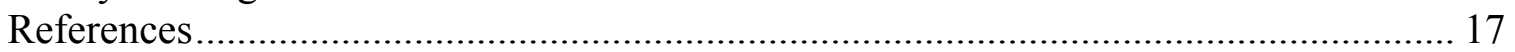

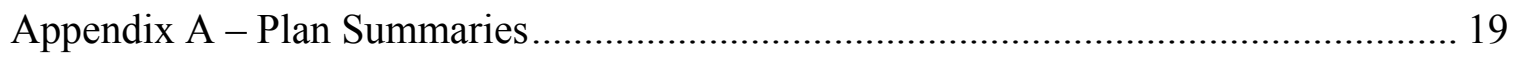

Appendix B - List of Selected National Energy Plans ............................................... 32

Appendix C - Additional Selected Policy Recommendation Examples ......................... 36 


\section{List of Figures}

Figure 1. Illustration of the "Three E" geography and momentum as of early 2009 ......... 1

Figure 2. Comparison of selected renewable energy targets in the plans .......................... 6

Figure 3. Selected energy efficiency targets compared to the EIA baseline ..................... 8

Figure 4. Fuel economy for new passenger vehicles under the plans............................. 9

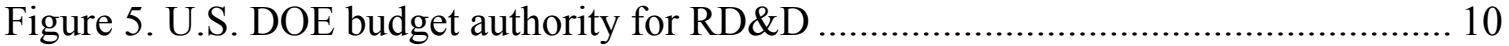

\section{List of Tables}

Table 1. Selected Energy, Environmental, and Economic Revitalization Plans ............... 2

Table 2. High-level Characterization of the Energy Plans ............................................... 3

Table 3. Examples of Vision Targets Proposed in Energy Plans .................................... 5

Table 4. Job Growth Intensity per Investment of Federal Spending ................................ 9

Table 5. Examples of Policy Mechanisms Proposed in Energy Plans.............................. 12 


\section{Introduction}

Policy makers have witnessed a surge of advice on how to address increasing energy prices, oil import dependency, and greenhouse gas emissions. More recently, the advice has become tailored to the pronounced financial and economic crisis affecting the globe. This paper summarizes recommendations of 12 formalized energy plans (which are listed in Table 1) and compares the targets that some propose. It also evaluates selected implementation challenges for RE and EE technologies targeted in the plans.

Only those plans released in the second half of 2008 are considered, because the economic downturn, elections, and collapse of energy prices have redrawn the political and economic landscape. To maintain a manageable evaluation, we limited our scope to a dozen diverse and high-profile plans.

The energy plans evaluated here acknowledge that energy security, environmental protection, and economic revitalization - the "Three Es" - are critical issues, even if they are valued differently. Figure 1 illustrates how the Three Es might overlap at a point in time. Beginning in late 2008, political momentum began shifting away from energy security as energy prices fell, while it built for economic stimulus as the economy increasingly faltered (see arrows in figure). Perception of where the center lies has shifted since the economic meltdown.

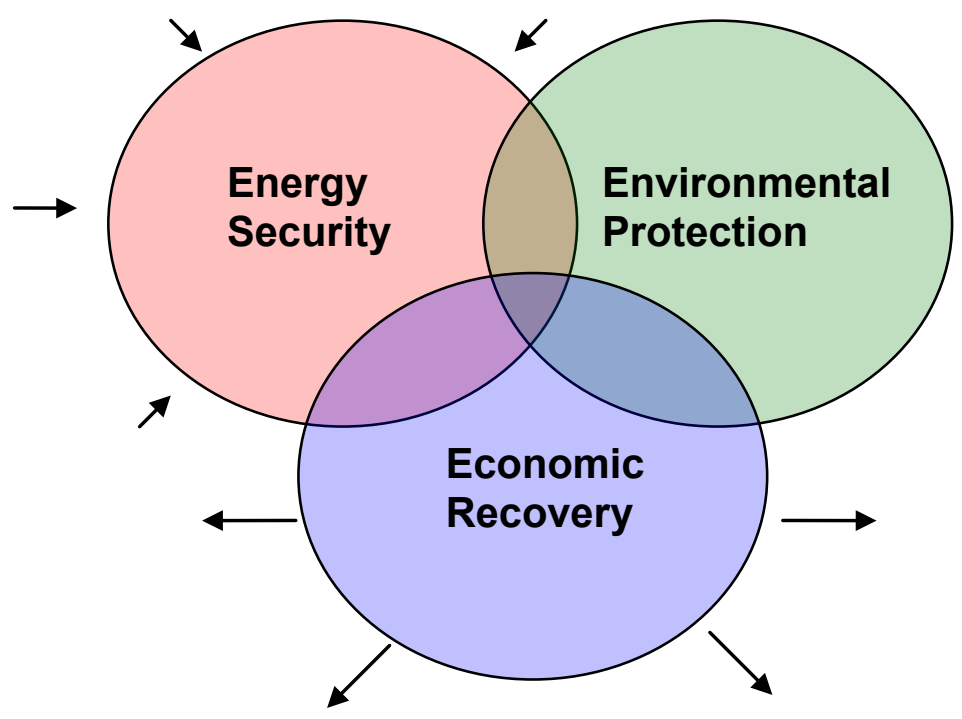

Figure 1. Illustration of the "Three E" geography and momentum as of early 2009

The paper is organized as follows: Section 2 compares and contrasts vision targets for the plans as well as the policy recommendations, (if available) to achieve them. Section $\mathbf{3}$ summarizes key findings from this evaluation. A brief one-page summary of each plan is found in Appendix A. A more complete list of energy and environmental plans for the new administration and Congress is in Appendix B. A more complete list of policy recommendations in the 12 plans is included in Appendix C. 
Table 1. Selected Energy, Environmental, and Economic Revitalization Plans

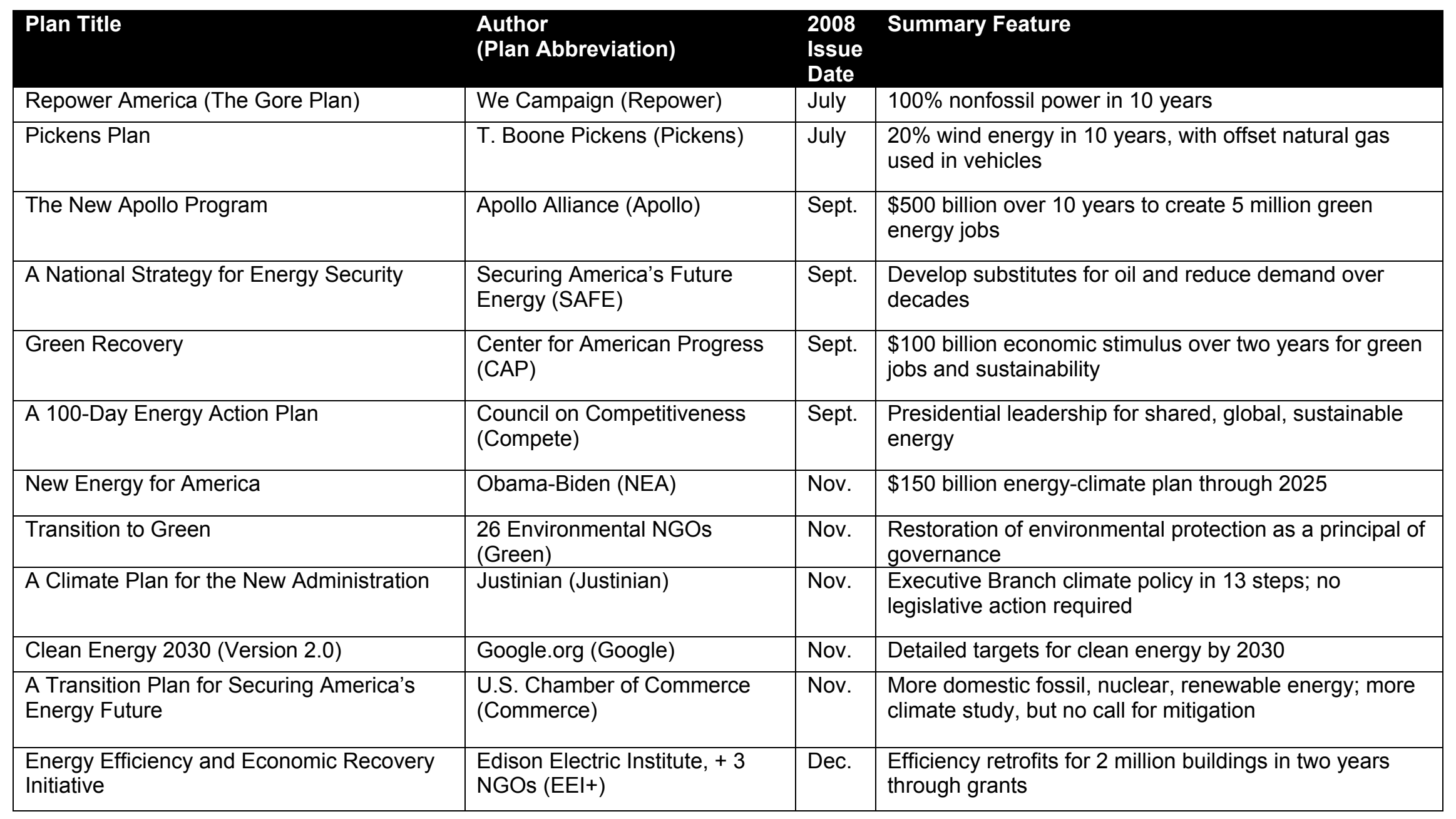




\section{Comparing Plan Characteristics}

This section compares and contrasts major characteristics of the plans. Despite the often-similar objectives in addressing the Three Es, significant differences exist in plan timescales, mechanisms, and level of detail. These are addressed in Table 2, which summarizes the "who, what, when, and how" of the plans.

Table 2. High-level Characterization of the Energy Plans

\begin{tabular}{|l|c|c|c|c|c|}
\hline \multicolumn{1}{|c|}{ Plan } & Primary Sector & Primary Focus & Timescale & $\begin{array}{c}\text { How } \\
\text { Mechanism }\end{array}$ & Cost Detail \\
\hline Repower & Power/Transport & Environment & Mid & Goals & No \\
\hline Pickens & Power/Transport & Security & Mid & Goals & No \\
\hline Apollo & All & Env/Econ & Mid & Mixed & Ceiling \\
\hline SAFE & All & Security & Long & Mixed & No \\
\hline CAP & Power/Buildings & Econ/Env & Short & Mixed & Ceiling \\
\hline Compete & All & Econ/Env & Long & Goals & No \\
\hline NEA & All & Econ/Env & Long & Mixed & Ceiling \\
\hline Green & Government & Environment & Short & Details & No \\
\hline Justinian & Government & Environment & Short & Details & No \\
\hline Google & Power/Transport & Environment & Long & Goals & Yes \\
\hline Commerce & All & Security & Long & Details & No \\
\hline EEl+ & Buildings & Econ/Env & Short & Details & Yes \\
\hline
\end{tabular}

Primary Sectors: Power, Transport, Buildings, and/or primarily addresses the public sector (Government).

Primary Focus: Economic Recovery, Energy Security, and, Environment (the 3 Es).

Timescale: Short, 0-5 years; Mid, 5-15 years; Long, beyond 15 years.

Primary Mechanism: Goals, top-down targets; Details, bottom-up planning; Mixed, combination.

Cost Detail: No, offers limited or no cost details; Ceiling, only total cost/spending ceiling; Yes, provides details about spending, policy economic impacts, and/or calculation methods.

Characterizing the plans at a high level can be difficult because they often try to address more than one issue, intentionally or not. The characterizations in Table $\mathbf{2}$ are thus preliminary and open to other interpretation.

The Primary Sector column considers who (which sectors) the plan is focused on: power, transport, buildings, government, or some other combination. Many of the plans offer recommendations across the entire economy (Apollo, NEA), while a few restrict themselves to selected sectors (EEI+, Repower). Primary Focus refers to the most fundamental element of the Three Es that drives the plan. Some plans have a singular focus (Green: environment), while others prioritize the pursuit of different objectives (Pickens: "security is on page one, climate is on page two"). All plans focus on immediate steps that the administration or Congress can take to address national goals, but some use a long-term horizon (Google, SAFE) while others look more specifically at economic recovery over the short term (CAP, EEI + ). The Primary 
Mechanism column refers to the level of detail in the plan regarding implementation: Does it offer rich policy and implementation detail, or is it goal-based and inspirational in nature? Finally, the Cost Detail column indicates whether the plan provides estimates of the economic costs of implementation. Some plans note a cost ceiling (Apollo, NEA), but provide little additional insightful information. Google appears to be the only plan that uses a model, or bottom-up approach, to estimate total costs for deployment.

\section{A. Quantitative Targets}

Some of the plans have quantifiable energy, environmental, and economic targets.

Table 3 provides select examples of these targets. These targets often exist independently of policy levers, cost assessments, and evaluations of technical feasibility.

Comparing renewable energy targets among plans that include them can help illustrate feasibility. The first bar in Figure 2 shows actual generation of renewable electricity in 2007 by type as a portion of total national electricity generation. Renewable sources provided $8.5 \%$ of total electricity generated in 2007, of which hydropower accounted for about $70 \%$, biomass $15 \%$, wind $9 \%$, geothermal $5 \%$, and solar $0.1 \%$. The remaining power comes from coal $(51 \%)$, natural gas $(18 \%)$, nuclear $(21 \%)$, and other sources $(1.5 \%)$ shown in the "nonrenewable generation" portion of the stacked bar (EIA 2008).

On January 8, 2009, President-elect Barack Obama called for a doubling of renewable energy production within three years. An aide later clarified that the statement referred to wind, geothermal, and solar electricity only - no doubling of hydro or biomass production was intended (Power and Talley 2009). Achieving this goal is represented in the second column (2012 Doubling) of Figure 2. The Pickens Plan estimate in the third column assumes that all currently forecasted natural gas generation in that year is replaced with wind power. Repower and Google directly note estimates in their respective plans. For reference, the $25 \%$ renewable portfolio standard in 2025 endorsed by New Energy for America and others is shown as a solid black column because there is no breakdown of how different renewables would contribute. Finally, Figure 2 shows the DOE evaluation of a 20\% wind energy target for $2030 .^{1}$

\footnotetext{
${ }^{1}$ According to the EIA's latest “Annual Energy Outlook," total net generation in 2030 is forecasted at 4,811 terawatt hours (TWh), corresponding to a 20\% wind target of 962 TWh. See also DOE 2008a.
} 
Table 3. Examples of Vision Targets Proposed in Energy Plans

\begin{tabular}{|c|c|c|c|}
\hline \multicolumn{2}{|c|}{ Issue } & Selected Vision Targets & \multirow{2}{*}{$\begin{array}{l}\text { Plan } \\
\text { CAP }\end{array}$} \\
\hline \multirow{3}{*}{\multicolumn{2}{|c|}{ Job Creation }} & 2011 target to create 2 million jobs from a $\$ 100$ billion investment in $\mathrm{EE}$ and RE technologies & \\
\hline & & 2019 target to create 5 million jobs from a $\$ 500$ billion investment in $\mathrm{EE}$ and $\mathrm{RE}$ technologies & Apollo \\
\hline & & 2019 target to create 5 million jobs from a $\$ 150$ billion investment in $\mathrm{EE}$ and $\mathrm{RE}$ technologies & NEA \\
\hline \multirow{2}{*}{\multicolumn{2}{|c|}{$\begin{array}{l}\text { Carbon Emissions } \\
\text { Reductions }\end{array}$}} & 2030 target to reduce carbon levels $35 \%$ below 2008 levels & Green \\
\hline & & 2050 target to reduce carbon levels $80 \%$ below 1990 levels & NEA; CAP \\
\hline \multirow{3}{*}{\multicolumn{2}{|c|}{ Fossil and Nuclear Energy }} & 2020 target to reduce U.S. dependence on foreign oil by one-third & Pickens \\
\hline & & 2030 target to increase nuclear electricity generation $15 \%$ from 2007 levels & Google \\
\hline & & Construct 10 coal demonstration plants using carbon capture and storage (CCS) technology & Apollo \\
\hline \multirow{5}{*}{$\begin{array}{l}\text { Renewable } \\
\text { Energy }\end{array}$} & \multirow[b]{2}{*}{$\begin{array}{l}\text { Federal } \\
\text { Targets }\end{array}$} & 2020 target to generate $100 \%$ of electricity from nonfossil energy & Repower \\
\hline & & 2025 target to generate $25 \%$ of electricity from renewable sources & $\begin{array}{l}\text { NEA; CAP; Apollo; } \\
\text { Green }\end{array}$ \\
\hline & \multirow{3}{*}{ R\&D } & Double public funding, at a minimum, for energy R\&D & $\begin{array}{l}\text { CAP; Commerce; } \\
\text { Apollo; Green }\end{array}$ \\
\hline & & Triple public funding for all energy R\&D & Compete \\
\hline & & Tenfold increase in public funding for all energy R\&D & SAFE \\
\hline \multirow{8}{*}{$\begin{array}{l}\text { Energy } \\
\text { Efficiency }\end{array}$} & \multirow{2}{*}{$\begin{array}{l}\text { Reducing } \\
\text { Demand }\end{array}$} & Reduce electricity demand $28 \%$ by 2020 (from projected demand) & Repower \\
\hline & & Reduce electricity demand $15 \%$ by 2020 (from projected demand) & NEA \\
\hline & \multirow{2}{*}{ Buildings } & 2011 target to retrofit 2 million existing buildings & $\mathrm{EEI+}$ \\
\hline & & 2025 target to reduce electrical demand in new and existing buildings by $30 \%$ & Apollo \\
\hline & \multirow{3}{*}{$\begin{array}{c}\text { Fuel } \\
\text { Economy }\end{array}$} & 2020 target to increase light-duty average fuel economy to at least $42 \mathrm{mpg}$ & Green \\
\hline & & 2030 target to increase average fuel economy to $51 \mathrm{mpg}$ & Google \\
\hline & & $4 \%$ annual increase in average fuel economy & NEA; SAFE \\
\hline & $\begin{array}{l}\text { Vehicle } \\
\text { Fleet } \\
\text { Diversity }\end{array}$ & $\begin{array}{l}\text { Transform the fleet of light-duty vehicles; plans list near-term ( }<10 \text { years) targets to accelerate } \\
\text { use of nonconventional vehicle technologies, including compressed natural gas (CNG), flex-fuel, } \\
\text { plug-in hybrid, and electric vehicles. }\end{array}$ & $\begin{array}{l}\text { SAFE; NEA; Pickens; } \\
\text { Google; CAP; } \\
\text { Commerce }\end{array}$ \\
\hline \multicolumn{2}{|c|}{ Grid Infrastructure } & 2030 target to expand transmission capacity by 20,000 miles $^{2}$ & Google \\
\hline
\end{tabular}

\footnotetext{
${ }^{2}$ This recommendation was proposed in DOE 2008a.
} 


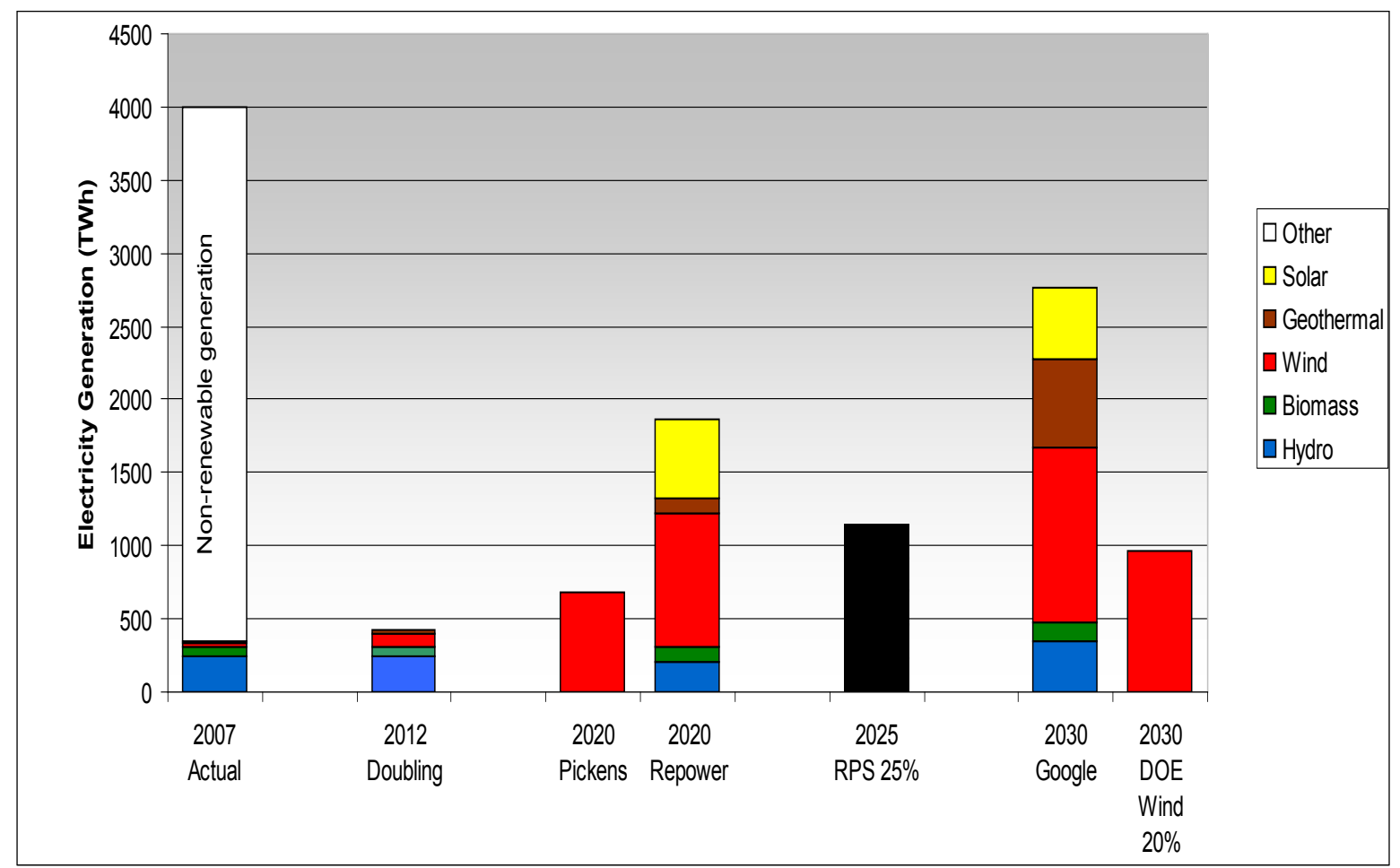

Note: Biomass refers to wood and various wastes; solar refers to photovoltaic and thermal energy. The $25 \%$ RPS column is black because its renewable power components are unknown (EIA 2008)

Figure 2. Comparison of selected renewable energy targets in the plans

\section{Wind Targets}

Doubling wind power output by 2012 would require the installation of about $8 \mathrm{GW}$ of new wind capacity each year. Thus, the amount of wind power installed in 2008 would need to be continued for three additional years. On February 17, 2009, President Obama signed the American Recovery and Reinvestment Act, P.L. 111-5, which modifies the renewable energy tax credits. In particular, the economic recovery law extends the wind production tax credit (PTC) through 2012, and offers new options to exchange the PTC for grants or an investment tax credit (ITC) to compensate for the recent decline in investments. These modifications are likely to boost investments in renewable energy over the near term compared to the situation before approval of the law, but the economic crisis casts a shadow of uncertainty over everything.

Direct comparison of different plans must account for differences in their time horizons. Although wind penetration rates for DOE and Pickens are both roughly $20 \%$ of total electricity generation, DOE's target assumes an extra 10 years of deployment, and higher overall power demand at that time. The targets given for Repower (27\%) and Google (29\%) are not directly comparable with the DOE level because both plans assume significantly lower forecasted electricity demand in the future due to efficiency and demand-reduction measures. Also important, the market pressures (materials availability, manufacturing capacity, workforce capacity, etc.) that could emerge from wind deployment over a 10 -year schedule compared to a 20 -year schedule may be significant. Deployment under the shorter schedule would likely result in higher costs per unit of 
wind power delivered. The wind industry was considered "overheated" during the past few years when roughly 5-8 GW of capacity were installed each year. ${ }^{3}$ The Pickens and Repower plans would require nearly an order of magnitude increase in annual installations to meet their targets in 10 years.

\section{Solar Targets}

The most aggressive target for any renewable energy source is that offered by Repower for solar energy (photovoltaic and solar thermal with storage). Meeting its goal would require installing more than $200 \mathrm{GW}$ of solar (with storage capacity) within 10 years, in addition to building transmission lines and installing a range of smart-grid technologies. For comparison, the Google plan envisions even greater solar capacity in 2030 (250 GW), but does so with an extra decade of time and fewer assumptions about storage capability. Of this total, the Google plan envisions $80 \mathrm{GW}$ of concentrated solar power (CSP) and $170 \mathrm{GW}$ of photovoltaic generating capacity. ${ }^{4}$

\section{Other Renewable Energy Targets}

The Google plan places the highest expectations on geothermal energy, both traditional and enhanced, with about $80 \mathrm{GW}$ installed by 2030 , accounting for $15 \%$ of total national generation.

Finally, several of the plans call for a national renewable energy portfolio standard of $25 \%$ by 2025 . Pursuing the DOE wind value of $20 \%$ wind by 2030 , or any of the other plans shown in Figure 2, would put the country on course to achieve the RPS target at an aggregate level, but specific policy design issues would influence if and how it is accomplished.

\section{Efficiency Targets}

Figure 3 illustrates the 2009 EIA baseline electricity demand forecast through 2030 and compares it to targets from selected plans. For comparison, the EIA's forecast from 2007 is also included, before the impacts of the Energy Independence and Security Act (EISA) of 2007 legislation and the economic downturn.

\footnotetext{
${ }^{3}$ Many researchers believe the on-again, off-again nature of the production tax credit (PTC) contributed to this overheating. See, for example, Wiser 2007.

${ }^{4}$ For comparison, the United States had just more than $1 \mathrm{GW}$ of installed photovoltaic and just under 0.5 GW of installed CSP generating capacity at the end of 2008 (Sherwood 2009). Globally, total installed photovoltaic generating capacity at the end of 2008 was approximately 10 times higher than the level in the United States. A rich pipeline of CSP projects is under development in Spain, the United States, and other countries.
} 


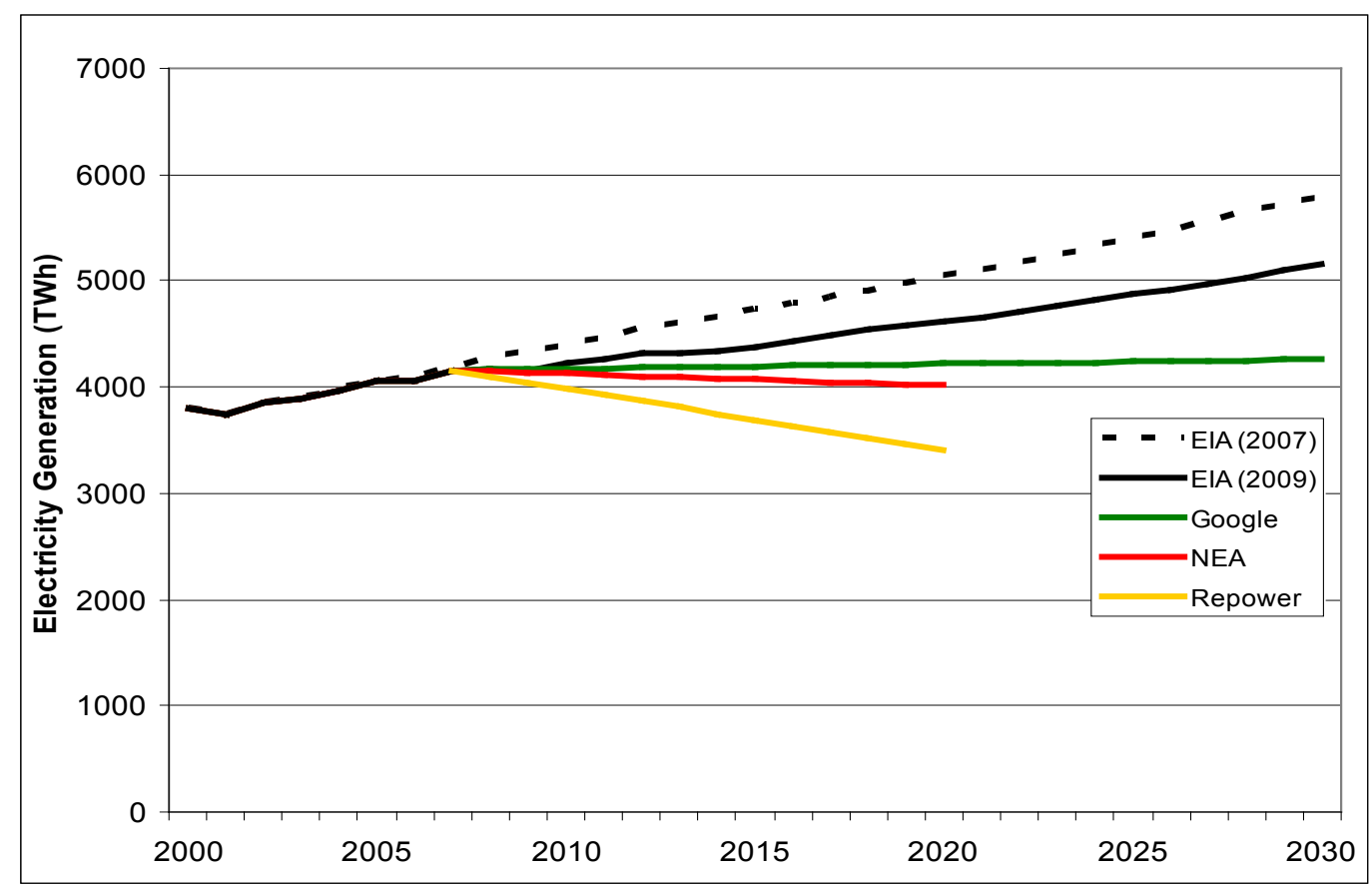

Source: EIA forecast is from "Annual Energy Outlook," early release 2009

Figure 3. Selected energy efficiency targets compared to the EIA baseline

Again, Repower has the most aggressive target for electricity efficiency improvements, averaging about $2.6 \%$ per year in electricity demand reductions compared to the reference EIA forecast. California held its per capita electricity demand flat during the past 30 years, demonstrating the flat Google target on a smaller scale (Chang et al. 2007).

Many experts think the potential to reduce electricity demand through efficiency and conservation is significant, and also the lowest-cost option to meet marginal power and carbon abatement (McKinsey 2009). Although Repower's efficiency target is almost certainly technically achievable, estimating the cost and effort required to do so would depend on economic, political, technical, and social factors beyond the scope of this analysis.

Finally, several of the plans recommend changes in corporate average fuel economy (CAFE) requirements for passenger vehicles as shown in Figure 4. The Energy Independence and Security Act (EISA) of 2007 requires that new passenger vehicles achieve 35 miles per gallon (mpg) in 2020. The Green target is the most aggressive among those shown and calls for $42 \mathrm{mpg}$ in 2020, rather than EISA's $35 \mathrm{mpg}$. This corresponds to an average annual increase of approximately 5\%. The NEA and SAFE plans suggest a 4\% annual increase (the latter only after the 2020 EISA provisions are met, while the former implies that it should begin immediately). The Google plan recommends a 2030 target of $45 \mathrm{mpg}$, but uses the more conservative EIA interpretation of efficiency compared to EPA's; it is converted in the figure to be comparable to the other targets. For comparison, existing requirements for Japan and proposed requirements for Europe are also included. 


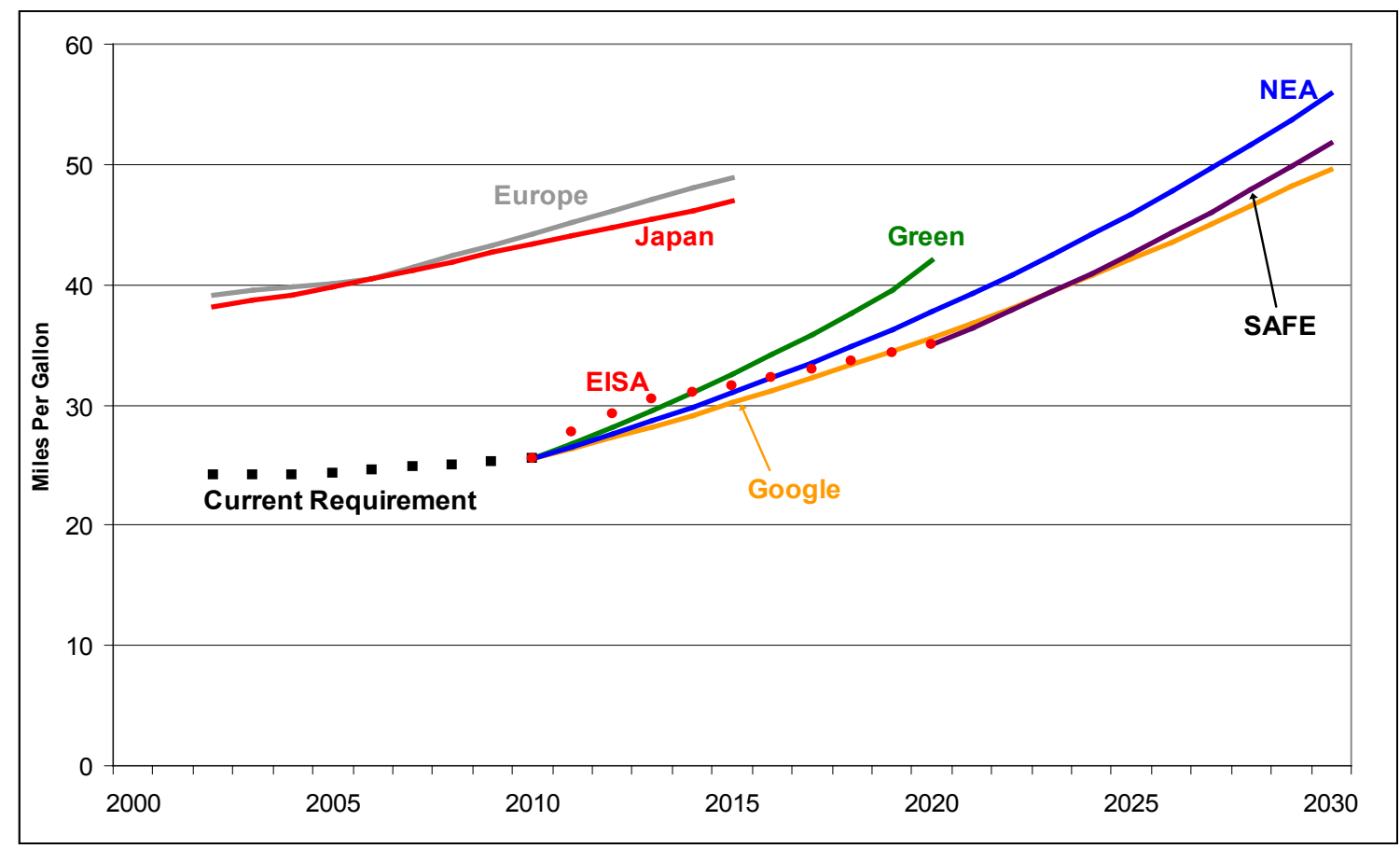

Source: Plan data, Feng et al. 2008, ICCT 2008

Figure 4. Fuel economy for new passenger vehicles under the plans

\section{Green Jobs Growth Targets}

Some plans provide estimates of the number of new green jobs that would be created through their policy recommendations. A major debate exists among academics and analysts over how to accurately estimate the net impacts and value of green job creation. This debate is reflected in the range of estimates from the three plans compared in Table 4.

Table 4. Job Growth Intensity per Investment of Federal Spending

\begin{tabular}{|c|c|c|}
\hline Plan & Jobs Created per $\$ 100 k$ Invested & Goal \\
\hline CAP & 2 jobs (over 2 years) & $\begin{array}{l}2011 \text { target to create } 2 \text { million jobs from a } \\
\$ 100 \text { billion investment }\end{array}$ \\
\hline Apollo & 1 job (over 10 years) & $\begin{array}{l}2019 \text { target to create } 5 \text { million jobs from a } \\
\$ 500 \text { billion investment }\end{array}$ \\
\hline NEA & 3.3 jobs (over 10 years) & $\begin{array}{l}2019 \text { target to create } 5 \text { million jobs from a } \\
\$ 150 \text { billion investment }\end{array}$ \\
\hline
\end{tabular}

\section{Comparative R\&D Targets}

Several plans recommend substantially higher funding for public energy R\&D, shown historically in Figure 5. Methods to calculate and display public energy R\&D investments differ based on variable definitions and the use of real versus nominal spending data. 


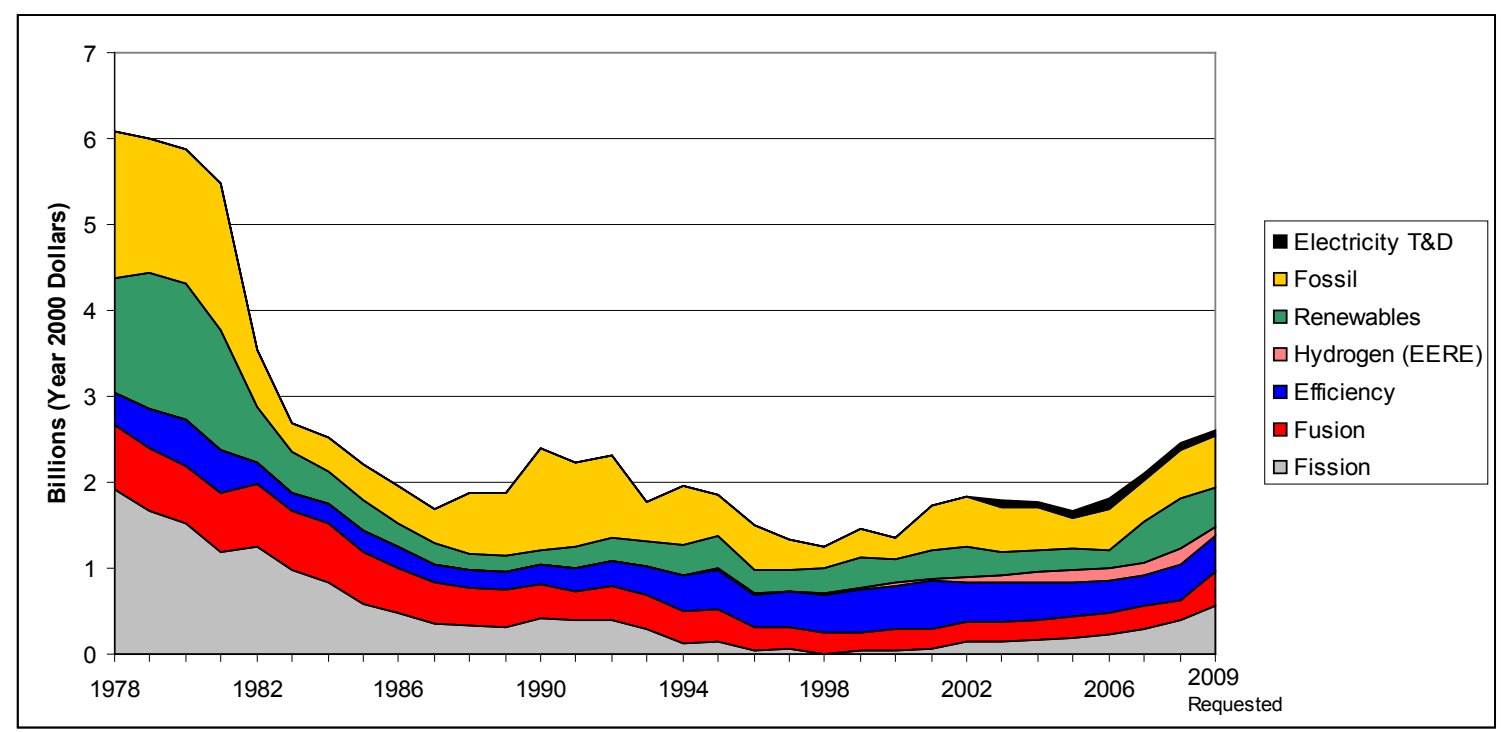

Source: Gallagher 2008

Figure 5. U.S. DOE budget authority for RD\&D

For 2008, about $\$ 2.6$ billion of funding went into seven core programs at the U.S. Department of Energy; if research for basic energy sciences is added, it includes about another $\$ 900$ million. The SAFE plan estimates current federal energy R\&D spending at $\$ 3$ billion per year, and calls for a tenfold increase to about $\$ 30$ billion per year. This increased level, SAFE notes, is on par with public health-related research, but still less than half of funding for research related to national defense. Institutional challenges associated with managing this substantial and near-term funding increase are not addressed in detail by SAFE.

The Green plan estimates current energy R\&D spending at $\$ 3.5$ billion per year, of which the plan notes about one-fifth, or $\$ 700$ million, is for DOE's Office of Energy Efficiency and Renewable Energy (EERE). A paper by the Congressional Research Service notes, however, that recent EERE funding is more than $\$ 1$ billion annually (Matthews et al. 2007). The Green plan recommends more than doubling the funding for EERE R\&D, in addition to reducing funding for fossil and nuclear energy. By 2013, Green recommends funding EERE with $\$ 3.2$ billion per year.

Other plans offer less detail. Commerce recommends doubling energy R\&D, referencing specific nuclear and fossil projects in addition to EERE options. Similar to the Green plan, Apollo and CAP recommend at least doubling R\&D funding for low-carbon technologies. And finally, Compete advocates for a threefold increase in energy R\&D funding across all federal agencies.

It is unclear whether these recommended $R \& D$ increases are at levels sufficient to reach the plans' future targets. No plans offer details on the appropriate rate of R\&D funding scale-up that will effectively reduce levels of redundancy or waste. And while some plans offer details on research priorities and pilot projects (e.g., CCS), forward-looking analysis about how the national energy R\&D portfolio may change to meet explicit national energy goals is limited. 


\section{B. Policy Measures}

This section compares and contrasts policy recommendations in the plans. Examples of selected recommendations are identified in Table 5, and an expanded list is found in Appendix C. We do not attempt to evaluate the implementation challenges of these recommendations because there is generally little information in the plans on key policy design issues. In some cases, we do highlight important policy design issues to consider.

Policy suggestions often refer to or otherwise align with initiatives in the combined energy bills of 2005 and 2007, the Energy Policy Act (EPAct) of 2005, and EISA, respectively. The plans frequently suggest fully funding or further expanding existing activities defined by these bills, especially those aimed at deploying EE and RE options.

The recommendations of the Green, Compete, and Justinian plans are often agencyspecific, detailing programmatic and institutional changes within the federal structure. White House and Cabinet officials can drive these agency recommendations without the need for legislative action. Plans such as Apollo and SAFE give a range of agencyspecific and legislative-based policy recommendations, providing a more global perspective on the federal government's powers to enact change. Commerce's approach is similar: to promote agency and legislative changes, as well as suggesting issues for further analysis prior to any federal action. Pickens and Repower provide few policy options to reach their vision targets, so they are not included in Table 5.

Several of the plans call for an RPS target. None of them provide policy detail on implementing RPS legislation such as what technologies are eligible, who is exempted, and how credits are traded. Several congressional bills are under development that call for a national RPS and will likely be debated in the first half of $2009 .^{5}$

\footnotetext{
${ }^{5}$ Senator Bingaman released a draft discussion paper in late January 2009 calling for a $20 \%$ RPS by 2021 ; Representative Markey introduced legislation in early February for a 25\% RPS by 2025.
} 
Table 5. Examples of Policy Mechanisms Proposed in Energy Plans

(see Appendix C for a more complete list of Policy Recommendations)

Issue

\section{Job Creation}

\begin{tabular}{|l|l|} 
& training initiatives \\
\hline \multirow{2}{*}{$\begin{array}{c}\text { Carbon } \\
\text { Emissions }\end{array}$} & $\begin{array}{l}\text { Raise the priority of national } \\
\text { energy and climate strategy }\end{array}$ \\
\cline { 2 - 3 } & Reduce carbon emissions
\end{tabular}

Emissions

\begin{tabular}{|l|l|}
\hline & $\begin{array}{l}\text { Expand domestic fossil } \\
\text { energy production }\end{array}$ \\
\cline { 2 - 3 } &
\end{tabular}

\begin{tabular}{|l|l|}
\multirow{2}{*}{$\begin{array}{c}\text { Fossil and } \\
\text { Nuclear } \\
\text { Energy }\end{array}$} & $\begin{array}{l}\text { Accelerate commercial use } \\
\text { of carbon-reduction } \\
\text { technologies }\end{array}$ \\
\cline { 2 - 2 } & $\begin{array}{l}\text { Reduce or eliminate fossil } \\
\text { energy subsidies }\end{array}$ \\
\cline { 2 - 2 } &
\end{tabular}

\begin{tabular}{|c|c|}
\hline & \\
\hline & Safer nuclear energy use \\
\hline & $\begin{array}{l}\text { Enhance use of the } \\
\text { strategic petroleum reserve } \\
\text { (SPR) }\end{array}$ \\
\hline \multirow{2}{*}{$\begin{array}{l}\text { Renewable } \\
\text { Energy }\end{array}$} & $\begin{array}{l}\text { Spur renewable energy } \\
\text { R\&D and commercialization }\end{array}$ \\
\hline & $\begin{array}{l}\text { Spur renewable energy } \\
\text { markets and installations }\end{array}$ \\
\hline \multirow{2}{*}{$\begin{array}{l}\text { Energy } \\
\text { Efficiency }\end{array}$} & $\begin{array}{l}\text { Reduce electricity demands } \\
\text { from buildings }\end{array}$ \\
\hline & $\begin{array}{l}\text { Increase fuel economy and } \\
\text { diversify vehicle fleet }\end{array}$ \\
\hline \multirow{2}{*}{$\begin{array}{c}\text { Grid } \\
\text { Infrastructure }\end{array}$} & Advance smart grid \\
\hline & $\begin{array}{l}\text { Expand transmission } \\
\text { capacity }\end{array}$ \\
\hline
\end{tabular}

\section{Select Examples of Policy Recommendations}

- Congress should fully fund the America COMPETES Act (Commerce).

- The federal government should create a Clean Energy Jobs Corp to promote "green collar" jobs (CAP).

- $\quad$ Create a White House National Energy Council to lead all other agencies in making energy and global climate change a top administration priority (CAP).

- Implement an economy-wide, cap-and-trade program to reduce GHG emissions $80 \%$ below 1990 levels by 2050 . Auction carbon permits and use the generated revenues to invest in clean energy (Green).

- Increase access to resources on the outer continental shelf, with environmental protections (SAFE).

- $\quad$ Enact "use it or lose it" approach to existing oil leases (NEA).

- $\quad$ EPA should establish new source performance standards (NSPS) for coal-fired power plants consistent with the use of integrated gasification combined-cycle (IGCC) technology (Justinian).

- Congress should enact a new tax credit to retrofit existing coal-fired power plants - including those of less than $400 \mathrm{MW}$ (Commerce).

- $\quad$ Create an Energy Subsidies Commission, operated analogously to the Defense Base Closure and Realignment Commission (BRAC), to prioritize energy subsidy reform (Justinian).

- Suspend Yucca Mountain nuclear waste repository program and develop secure on-site storage (Green).

- Release petroleum products tactically to address high oil prices. (NEA).

- $\quad$ Create a National Energy Innovation Fund to fund demonstration projects with others (Apollo).

- Direct the secretaries of Treasury and Energy to propose legislation to establish a $\$ 200$ billion National Clean Energy Bank to provide long-term financing for breakthrough EERE technologies (Compete).

- $\quad$ Establish a 25\% federal renewable portfolio standard (RPS) by 2025 (NEA).

- Direct the Federal Energy Regulatory Commission (FERC) to set national interconnection standards for an interoperable grid and transmission system capable of connecting multiple new energy sources and devices (Compete).

- Prioritize block grants to states/regions where utilities "decouple" electricity regulation (NEA).

- Congress should establish targets for the residential and commercial model energy building codes to increase EE savings by at least $30 \%$ by 2010 and $50 \%$ by 2020 (EEl+).

- Consider mechanisms such as "feebates" consumer and manufacturing incentives, and cash incentives or vouchers to accelerate conventional vehicle turnover (Google).

- Require FERC to modify rates of return on investments to modernize the electrical grid (Apollo).

- Modify DOE's existing authority under Section 216(h) of the Federal Power Act, designating DOE as the lead agency to coordinate permits required for interstate transmission (within two years) (Commerce). 
Most plans call for dramatically improved efficiency in the building sector over the medium- to long term (NEA, Repower, Apollo). Based on aggressive efforts in the draft House economic stimulus legislation, short-term efforts may help support the longerrange goals. EEI+ and CAP call for federally administered block grant funding to support existing building efficiency programs at the state and local level.

While many policies overlap among the plans, strong differences exist on the objectives and subsequent policy measures to address nuclear energy, fossil fuels, carbon emissions, and vehicle efficiency.

Nuclear energy proponents (Commerce and SAFE) cite the technology's ability to address energy security and low carbon needs, yet other plans (NEA and Google) do not recommend aggressive expansions without improvements in cost and waste disposal. The Green plan recommends a set of policies to substantially reduce the federal role supporting all new nuclear power generation.

Fossil fuel policies also vary. Some plans recommend incentivizing enhanced oil recovery processes (SAFE and NEA) and drilling on the outer continental shelf (Commerce and SAFE) to increase domestic oil production. Other plans recommend heightened drilling regulations (Green). Advancing carbon-capture and storage technology (CAP, SAFE, Commerce, NEA, Green, and Justinian) is commonly recommended, yet incentivizing the more commercially mature integrated gasification combined-cycle (IGCC) technologies (Commerce and Justinian) is less frequently noted.

Carbon mitigation recommendations often parallel those on fossil energy. Some plans (Justinian and Green) want carbon emissions to be regulated under the Clear Air Act (Commerce opposes this), in addition to broader support for a cap-and-trade system (Green, NEA, Apollo, and CAP). Many plans (especially EEI+) recommend greatly increasing targeted energy efficiency projects as a first means to reduce carbon emissions.

Most vehicle efficiency policies are driven by objectives to reduce foreign oil consumption and carbon emissions. Some plans seek to incentivize plug-in hybrid electric vehicles (PHEVs). Other plans (SAFE) offer a more comprehensive approach. The Pickens plan is known for targets to increase natural gas-powered vehicles; however, few policy details are offered and none of the other plans support such an aggressive transition to natural gas vehicles.

Finally, the plans offer a mix of economic figures and analyses tied to implementation. Google provides the most detailed cost summary for increased low-carbon technology deployment, summing individual plan components to give an overall cost estimate tied to its targets. A few plans (NEA, Google, and CAP) provide revenue estimates from capand-trade or vehicle "feebate" offset other taxes. Generally, plans either identify cost ceiling limits or note nothing at all.

\footnotetext{
${ }^{6}$ A feebate program is a self-financing system of fees and rebates, which are used to influence consumer behavior. In this example, rebates are offered to buyers of highly efficient vehicles, while fees are charged to those who purchase inefficient ones.
} 


\section{Key Findings}

Conclusions from this analysis of the energy plans are grouped into general and specific categories. Readers are likely to come to different conclusions about what the plans mean for U.S. energy policy given their fundamentally different objectives and methodology. Additionally, as the plans analyzed here are only one subset of a larger group of recommendations, these observations do not necessarily reflect those of the entire survey population.

\section{General Findings}

- Most energy plans evaluated here call for transformative change in energy policy. They argue that inconsistent national policy has contributed to damaging cyclical changes in energy markets during the past 35 years. Most plans imply that the nation can no longer escape the consequences of petroleum insecurity and climate change. Fundamental changes are needed to improve energy end-use efficiency, lower emissions, and lessen reliance on oil imports. The recent collapse in oil prices has not helped the environment for political leadership in this regard. However, some argue that the economic crisis opens the door of opportunity to think big in addressing perennial energy - and larger economic - problems.

- Most plans focus on broad recommendations for a new comprehensive energy policy rather than detailed design issues necessary for implementation in any one sector. Because of this, they lack detail on policy design issues that must be known to evaluate strengths and weaknesses of plan recommendations. Evaluating the challenges of a cap-and-trade recommendation, for example, depends on factors such as which sectors are included, how allowances are allocated or auctioned, and what role carbon offsets play. ${ }^{7}$ Similarly, a national RPS must consider the trade-offs of including carve-outs for specific technologies, designing renewable energy certificate (REC) trading markets, and resolving jurisdictional standing when state and federal requirements conflict (Perera et al. 2007). Additional follow-on analysis can help flesh out the policy design options in many of the plans.

- Recently introduced plans note that economic recovery is the first priority for the new Congress and administration. Whether the recovery law can integrate Keynesian spending with longer-term priorities such as carbon mitigation, oil import reductions, and a greener economy remains to be seen. Some short-term measures may contradict longer-term objectives (highway reconstruction vs. lower oil demand and emissions), while others may create unintended consequences (interaction of a national renewable portfolio standard with capand-trade legislation) (Houser et al. 2009).

- The plans illustrate the complexity of trying to prioritize national energy goals that focus on long-term needs while providing enough flexibility to deal with

\footnotetext{
${ }^{7}$ See, for example, Guesnerie and Tulkens 2009 or Burtraw et al. 2009.
} 
short-term requirements. Political leadership, as noted in some of the plans, could help catalyze a national discussion resulting in a more strategic, consistent federal role.

- Almost universally, plans call for an expansion of clean energy R\&D, EERE technology deployment, and climate change preparedness. But sharp contradictions also exist regarding domestic drilling, nuclear subsidies, climate mitigation targets, and the fundamental role of government. Unpredictable political dynamics within Congress, and between Congress and the administration, will influence the evolution of support for elements of the plans.

\section{$\underline{\text { Specific Findings }}$}

- Most renewable energy targets proposed by the plans are probably technically achievable in the timeframe considered, but the most aggressive ones are likely to come at high cost. Deploying $200 \mathrm{GW}$ of solar-generating capacity within 10 years, as one plan suggests, would likely create supply-chain tensions that cause a price increase.

- Over the short-run, many plans suggest that investments to improve building efficiency are an attractive policy option because they are quick to create employment and proven to cost-effectively reduce energy demand and emissions. $^{8}$ There are two building sectors to focus on: federal buildings, which could play an important role in stimulating efficiency markets and establishing a leadership role; and privately owned buildings, which are supported by the American Recovery and Reinvestment Act through existing state and local programs.

- The American Recovery and Reinvestment Act extends and reforms the production and investment tax credits for renewable power sources - a provision that some of the recent plans had recommended. These changes aim to build a foundation for renewable energy and green jobs over the longer term.

- About one-third of the plans analyzed call for expanded production of domestic fossil fuels and development of alternatives to petroleum. The collapse in energy prices since those plans were published has at least temporarily reduced momentum to address oil insecurity and may slow the search for long-term alternative transportation solutions. Many analysts believe the current low-price environment is temporary; when global demand begins growing again, oil supply will be caught unprepared, resulting in a return to high prices. ${ }^{9}$ These developments illustrate that national energy policy has yet to address the sometimes damaging cyclical nature of energy markets.

\footnotetext{
${ }^{8}$ This is the foundation of the EEI+ plan and a core element of many others. For more comprehensive analysis, see American Physical Society 2008.

${ }^{9}$ See, for example, Bordoff and Metcalf 2009 or Van de Veer 2009.
} 
- The plans generally acknowledge that new and expanded energy infrastructure is required to achieve transformative changes in the U.S. energy system. Yet most plans do not provide detail on how to best introduce new electric transmission capacity, electric vehicle-charging systems, or carbon capture and sequestration infrastructure. ${ }^{10}$ Policy design associated with this infrastructure deployment could have strong repercussions on clean energy technology development and evolution.

${ }^{10}$ Significant research has been conducted on these topics, however, outside of the plans. See the following examples: DOE 2008a; DOE 2008b; and Dooley et al. 2006. 


\section{References}

American Physical Society. (2008). “Energy Future: Think Efficiency,” September 2008.

Bordoff, J.; and Metcalf, G. (2009). "Breaking the Boom-Bust Oil Cycle" The New Republic, January 2009.

Burtraw, D.; Palmer, K.; and Kahn, D. (2009). “A Symmetric Safety Valve.” Resources for the Future, February 2009.

Chang, A.; Rosenfeld, A.; and McAuliffe, P. (2007). "Energy Efficiency in California and The United States: Reducing Energy Costs and Greenhouse Gas Emissions," in Schneider, Rosencranz, and Mastrandrea (Eds.) Climate Change Science and Policy, 2007.

Department of Energy (DOE). (2008a). U.S. Department of Energy. "20\% Wind Energy by 2030: Increasing Wind Energy's Contribution to U.S. Electricity Supply.” July 2008.

DOE. (2008b). U.S. Department of Energy. "Plug-in Hybrid Electric Vehicle Charging Infrastructure Review." November 2008.

Dooley, J.J.; Dahowski, R.T.; et al. (2006). "Carbon Dioxide Capture and Geological Storage: A Core Element of a Global Energy Technology Strategy to Address Climate Change." Pacific Northwest National Laboratory, April 2006.

Energy Information Administration (EIA). (2008). "Electric Power Monthly," December 2008, Table 1.1A.

EIA. (2006). "Electric Power Annual 2006," U.S. Energy Information Administration, Table 2.1.

Feng, A.; Gordon, D.; Hui, H.; et al. (2008). International Council on Clean Transportation, "Passenger Vehicle Greenhouse Gas and Fuel Economy Standards: A Global Update," Updated December 2008.

Gallagher, K.S. (2008). "DOE Budget Authority for Energy Research, Development, and Demonstration Database," Energy Technology Innovation Policy, John F. Kennedy School of Government, Harvard University, June 2008.

Guesnerie, R.; Tulkens, H.; eds. (2009). “The Design of Climate Policy.” MIT Press, January 2009.

Hargreaves, S. (2008). "Save Energy, Save the Economy," CNNMoney.com, December 14, 2008. 
Houser, T.; Mohan, S.; and Heilmayr, R. (2009). "Policy Brief: A Green Global Recovery? Assessing U.S. Economic Stimulus and the Prospects for International Coordination." World Resources Institute and the Peterson Institute for International Economics. February 2009.

Hudson Clean Energy Partners, L.P. (2009). "Additional Observations About the Impacts of Stimulus Action on Energy and Environmental Policy.” January 8, 2009.

International Council on Clean Transportation (ICCT). (2008). "Fuel Economy Standards and GHG Standards Charts in PowerPoint Format." Updated December 2008.

Jenkins, H. (2008). “Boone Doggle,” Wall Street Journal, August 6, 2008, p. A13.

Logan, J.; Hederman, W.; and Yacobucci, B. (2008). "The T. Boone Pickens Energy Plan: Preliminary Analysis of Implementation Issues," general distribution memo issued by the Congressional Research Service, October 1, 2008.

Matthews, C., et al. (2007). "Federal Research and Development Funding: FY08." Congressional Research Service, September 20, 2007.

McKinsey and Company. (2009). "Greenhouse Gas Abatement in the U.S. and the Role of the DOE's Office of Energy Efficiency and Renewable Energy," 2009 (forthcoming).

Perera, A.; Hanson, C.; Heilmayr, R. (2007). "National Renewable Electricity Standard Design Features.” World Resources Institute, December 2007.

Podesta, J.; Stern, T.; and Batten, K. (2007). "Capturing the Energy Opportunity: Creating a Low-Carbon Economy," in Progressive Growth: Transforming America's Economy through Clean Energy, Innovation, and Opportunity, Center for American Progress, November 2007.

Power, S.; and Talley, I. (2009). "Obama Team, Exxon Mobil Chief Trade Jabs on Energy," Wall Street Journal, January 8, 2009.

Sherwood, L. (2009). Interstate Renewable Energy Council, personal communication, February 2009.

Van de Veer, J. (2009). "Investing Through the Cycle: Challenges and Opportunities," speech given by chief executive of Royal Dutch Shell at CERA Week, Houston, TX, February 2009.

Wiser, R. (2007). "Wind Power and the Production Tax Credit: An Overview of Research Results," Testimony to the Senate Finance Committee, March 29, 2007, pp. 6-8. 


\section{Appendix A - Plan Summaries}

This appendix provides concise summaries of each of the 12 plans listed in Table 1, ordered chronologically according to their public release dates. We consider the main goals, how the plan envisions achieving them, and note special challenges. Because each summary is limited to one page, we focus only on selected issues. 


\section{Repower America (Repower)}

Repower America has an uncluttered goal: 100\% carbon-free electricity within 10 years. The plan was first articulated in a speech by Al Gore in July 2008. It calls for significant improvements in national energy efficiency, rapid deployment of renewable energy options, a unified national smart grid, and plug-in hybrid electric vehicles. The plan claimed to have more than 2 million supporters in late $2008,{ }^{11}$ more than the 1.4 million who support the Pickens Plan.

Repower America has specific "vision targets" for energy efficiency and renewable energy options (see box). With the exception of the efficiency target, little information is provided on what policies would drive the rapid expansion. The plan authors note that the technologies, investment, and supply chains required to achieve its goals are ready and would not present deployment constraints. This is a controversial statement for some, at least when considering costs and economic efficiency in such a short period.

\section{Selected Highlights of Repower America}

- Reduce projected national electricity demand by $28 \%$ in 10 years through a combination of building and appliance standards, regulatory reforms, and other incentives;

- Deploy 20-25 GW of geothermal, $110-180 \mathrm{GW}$ of solar thermal, $65-75 \mathrm{GW}$ of solar $\mathrm{PV}$, and $315-400 \mathrm{GW}$ of wind power within 10 years;

- Depending on conditions, deploy about $30 \mathrm{GW}$ (4\% of total power demand) of coaland gas-fired carbon capture and sequestration (CCS); and

- Deploy an undisclosed number of plug-in hybrid electric vehicles.

\section{Selected Implementation Challenges}

The wind and solar targets in this plan seem especially challenging. While the Department of Energy has reported that achieving 20\% wind energy by 2030 is feasible, the Repower America plan calls for 33-37\% wind energy within 10 years. This cannot be ruled out as impossible, although it is likely to come at a very high cost due to the market distortions that would likely result from such rapid growth. Similarly, installing $200 \mathrm{GW}$ or more of solar thermal and photovoltaics (PV) might be possible in theory, but little information is provided on how it would be incentivized.

Furthermore, the analysis does not provide an estimate of how much it would cost to decommission all existing fossil fuel power plants within 10 years, whether or not they have paid back their initial capital costs. More than $200 \mathrm{GW}$ of new natural gas power plants have been installed since 1995, for example, and retiring them early would strand the owners' assets (EIA 2006).

Finally, even if $30 \mathrm{GW}$ of coal- and gas-fired carbon capture and sequestration (CCS) could be installed within 10 years, these are not carbon-free sources of electricity because at least $10 \%$ of their carbon dioxide emissions cannot be readily captured.

${ }^{11} \mathrm{http}: / /$ www.wecansolveit.org/, accessed on December 13, 2008. 


\section{The Pickens Plan (Pickens)}

The T. Boone Pickens Plan, announced in July 2008, served to stimulate a national dialogue on energy policy and encouraged others to issue their own plans. The Pickens Plan has attracted wide attention due to its $\$ 56$ million outreach component and the fact that it was issued at the time of peak oil prices.

\section{Selected Highlights of the Pickens Plan}

- Deploy enough wind turbines and transmission capacity in 10 years to (largely) offset the need for natural gas in power generation;

- Use this natural gas in fleets of compressed natural gas (CNG) vehicles; and

- Offset the need to import about one-third of the nation's petroleum from the oil-toCNG conversions.

\section{Selected Implementation Challenges}

Some have claimed that the Pickens Plan suffers from an unnecessary "Rube Goldberg" complexity, and that the wind deployment does not have to be linked to natural gas vehicles to be effective. ${ }^{12}$ Others have noted the following implementation challenges with the Plan: ${ }^{13}$

- The Plan is likely to result in only about one-third of the reduction in oil imports as it claims. Two issues explain this potential discrepancy. First, only about half as much natural gas as the Plan claims would be displaced by wind turbines, because wind power offsets the need for coal as well as natural gas, and a portion of gas would still be needed for backup generation. Second, any petroleum offset by natural gas in vehicles would displace domestically produced oil as well as imports. The Plan is likely to offset more carbon dioxide than it claims, due to the reduction in coal-fired electricity, and the switch from petroleum to natural gas in vehicles.

- Wind turbine generation capacity would need to expand to approximately $260 \mathrm{GW}$ within 10 years to meet the goals of the Plan. While potentially feasible, such a rapid expansion could result in supply-chain distortions.

- For natural gas vehicles to consume the amount of gas offset by wind power as envisioned, about 75 million vehicles would need to be in service within 10 years. This would require a rapid ramp up in sales, accounting for nearly $100 \%$ of the new cars sold by 2018. Such a policy would likely restrict expansion of a proposed electric-vehicle fleet due to conflicting infrastructure requirements. Given the recent surge in new shale natural gas supply, substituting one form of energy insecurity for another is less likely under the Plan, but additional research is needed to confirm the long-term economics of shale gas production. The Plan was recently modified to focus on natural gas use in heavy-duty vehicle fleets instead of light-duty fleets.

\footnotetext{
${ }^{12}$ Goldberg was a cartoonist famous for drawing elaborate machines that performed simple tasks in convoluted ways (see Jenkins 2008).

${ }^{13}$ This critique of the Plan is taken largely from a general distribution memo issued by the Congressional Research Service (see Logan et al. 2008).
} 


\section{The New Apollo Program (Apollo)}

The Apollo plan - promoted by a coalition of business, labor, environmental, and community leaders - offers a blueprint for a fundamentally new economy. It is perhaps the most ambitious of all plans reviewed here. It aims to invest $\$ 500$ billion in clean energy initiatives over 10 years and create 5 million green-collar jobs. The plan puts special emphasis on restoring quality manufacturing jobs in the United States. The Apollo plan is more comprehensive than many of the other plans and targets both short- and long-term challenges. It makes no mention, however, of expanding domestic fossil fuel extraction or nuclear power.

\section{Selected Highlights of the Apollo Program}

- Pass a national renewable portfolio standard (RPS) of $25 \%$ by 2025 , and a 10 -year extension of the production and investment tax credits;

- Achieve a $20 \%$ reduction of energy use in new and existing buildings (and power plants) by 2025 through an Energy Smart Fund that grants federal dollars to state and local initiatives;

- Establish new transmission corridors and modernize the electrical grid;

- Double national investment in clean energy R\&D and incentives to build a green-collar workforce;

- Restore leadership in technology through a National Energy Innovation Fund that helps investors overcome the "valley of death" in bringing clean energy options to market;

- Improve power plant and industrial efficiency by $20 \%$ by 2025 through combined heat and power (CHP) and integrated gasification combined-cycle (IGCC);

- Demonstrate at least 10 carbon capture and sequestration plants; and

- Establish a "cap-and-invest" program to auction greenhouse gas emission allowances and invest the anticipated annual revenues of $\$ 50-300$ billion into new technology through a Clean Energy Investment Corporation.

\section{Selected Implementation Challenges}

The plan could face challenges in Congress due to its potential high costs and perception that too much control is placed in government hands. Evaluating the potential costs (and benefits) of the Apollo Program is complex, and it is difficult to estimate in advance how far $\$ 500$ billion will go toward meeting the goals. Some members of Congress may object to elements of the plan because of potentially high costs. Others might believe that government is unable to manage investment corporations or innovation funds effectively, even if the private sector has recently demonstrated its own weaknesses. Some may object to the program's aim to restore the power of labor unions in the manufacturing sector. Controversy over union demands is considered by some the stumbling point on mid-December legislation that would have provided short-term loans to protect the "formerly" Big Three domestic auto manufacturers. 


\section{A National Strategy for Energy Security (SAFE)}

The SAFE plan has attracted strong interest among those most concerned with national security. Although the recommendations are primarily focused on reducing oil dependence, the plan also acknowledges that climate protection is essential to national security. It recognizes that there are no simple measures to achieve energy independence; several decades of tough political choices will be required to find suitable and sufficient substitutes for oil.

The plan was released in September 2008, before the worst effects of the economic crisis appeared, so it does not address issues of economic recovery. As oil prices have fallen by more than $\$ 100$ per barrel since July 2008 , the political momentum to address energy insecurity has diminished. Given the poor global economic outlook, it is unlikely that higher energy prices will return - absent a major international security event - in time to allow this plan to regain the attention it once received.

\section{Selected Highlights of the SAFE Plan}

- Increasing tenfold federal energy R\&D to $\$ 30$ billion annually (and boosting advanced battery research to at least $\$ 500$ million per year);

- Extending the production and investment tax credits until 2013;

- Empowering FERC to ensure a robust and expanded transmission system;

- Eliminating tariffs on imported ethanol, and replacing existing \$0.45/gallon tax credit for domestic blenders with a "smart subsidy";

- Expanding access to domestic oil and gas resources; and

- Promoting a U.S.-China partnership on carbon capture and sequestration.

\section{Selected Implementation Challenges}

One potential concern in implementing the plan would be how to effectively spend the tenfold increase in energy $R \& D$, particularly in the early years. Careful ramping up of spending to ensure useful R\&D plans, and avoid duplication or waste, would be necessary.

The SAFE plan calls for consumer tax credits to spur the deployment of highly efficient vehicles. A credit of $\$ 4,000$ for the first 2 million vehicles, for example, would be offered for any vehicle that is twice as efficient as the relevant fuel economy standard for that year. It remains to be seen whether this would be an effective way to incentivize transportation efficiency if petroleum prices remain relatively low.

The plan also calls for an aggressive expansion of CCS activities, from roughly $\$ 100$ million annually today to $\$ 1.5$ billion within five years. Several demonstration projects (similar to FutureGen) would be supported, with the goal of determining whether CCS is technically, economically, and socially viable. Expanding cooperation with other large coal-users (China and India) on CCS seems a logical follow-on activity once the domestic questions are answered. 


\section{Green Recovery (CAP)}

In 2007, the Center for American Progress (CAP) issued a report on "Progressive Growth," one chapter of which outlined how to transition to a low-carbon economy (Podesta et al. 2007). Green Recovery, written primarily by political economists at the University of Massachusetts, is an attempt to jumpstart some of the recommendations in that chapter.

Green Recovery is a two-year plan to spend $\$ 100$ billion in six green infrastructure areas: building retrofits, mass transit and freight rail, smart-grid systems, wind power, solar power, and next-generation biofuels. It aims to create 2 million new jobs, especially in the construction and manufacturing sectors. Half of the $\$ 100$ billion would be directed to business and homeowner tax credits for building retrofits and renewable energy investments; $\$ 46$ billion would support expanded direct government spending on public building retrofits, mass transit, freight rail, smart grids, and renewable energy; and the remaining $\$ 4$ billion would go to federal loan guarantees that would underwrite additional investment. The plan would be paid for through deficit spending, but the authors estimate that energy savings would offset these up-front costs in about five years.

\section{Selected Highlights of the Green Recovery Plan}

- Require that all federal buildings are retrofitted for energy efficiency and renewable energy; encourage state and local governments to do the same;

- Extend and increase tax credits to encourage private-building owners and homeowners to perform similar retrofits;

- Expand federal support for state and municipal transit programs;

- Expand the Smart Grid Investment Matching Grant Program from EISA;

- Expand and extend renewable energy tax credits; and

- Provide loan guarantees for advanced biofuel production capacity.

\section{Selected Implementation Challenges}

This plan assumes rapid action by the federal government in retrofitting public buildings. It seems likely that many, if not most, federal buildings would require at least a year of planning before retrofitting could begin. Furthermore, the requirement is not clearly defined regarding which elements of public buildings (windows; lighting; heating, ventilation, and air conditioning systems or HVAC; etc.) should be prioritized for retrofitting.

The plan assumes that renewable energy developers will have an appropriate tax appetite to take advantage of extended tax credits. It remains to be seen whether recent reforms to renewable energy tax credits will sufficiently encourage investors (Hudson Clean Energy Partners 2009). Another variable is transmission capacity for massive renewable energy projects that the plan calls for-developers might be reluctant to make these investments without greater clarity on renewable energy transmission policy. 


\section{A 100-Day Energy Action Plan (Compete)}

The Council on Competitiveness - a group of CEOs, university presidents, and labor leaders committed to keeping the United States competitive in global markets - issued its 100-day energy action plan for the new administration in September 2008. The four-page plan states that the future economic competitiveness, national security, and prosperity of the nation will depend on an energy system that is sustainable, globally interconnected, and supported by all citizens. The Council notes that this plan is only the first step in achieving a sustainable, secure, and competitive energy system; it will convene a National Energy Summit in mid-2009 to issue a more comprehensive list of recommendations.

There are six key topics in the Council's plan: federal purchasing to promote energy efficiency, fully utilizing all domestic energy; catalyzing energy infrastructure investments; spawning technology breakthroughs and entrepreneurship; building a clean energy workforce; and clearing obstacles to a national transmission superhighway. Many are focused on entrepreneurism and innovation. Selected highlights are shown in the box below.

\section{Selected Highlights of the 100-Day Energy Action Plan}

- Direct key agency managers to work with leading experts to accelerate development, rapid adoption, and international recognition of cutting-edge energy efficiency standards, labeling, and verification systems;

- Direct Treasury to lead a "Clean Energy Incentives" task force to construct an investment framework that promotes affordable, clean energy;

- Propose legislation to establish a $\$ 200$ billion National Clean Energy Bank that provides long-term financing and incentives for breakthrough clean energy products and services;

- Triple current level of federal investment in basic and applied energy R\&D;

- Direct Labor to create a $\$ 300$ million "Clean Energy Workforce Readiness Program" to foster partnerships that ensure skilled workers in clean energy; and

- $\quad$ Direct FERC to create a regional transmission superhighway planning entity, giving them final authority for siting of transmission facilities.

\section{Selected Implementation Challenges}

This plan was published before the economic meltdown of late 2008, so there are few features aimed at immediate economic recovery. Furthermore, while the plan is focused on the actions during the first 100 days of the new administration, most of the programs recommended would require far more time to become operational.

The Cabinet-level working group on "Clean Energy Incentives" has a difficult task of establishing an investment framework to promote affordable, clean energy. The mandates of this recommendation seem to call for extensive restructuring of energy economics and governance. Furthermore, the $\$ 200$ billion National Clean Energy Bank might be difficult to capitalize at this point given the current and expected budget deficits. 


\section{New Energy for America (NEA)}

The new administration's plan calls for investing $\$ 150$ billion in clean energy technology development during the next 10 years to create 5 million new jobs. The outlays will be paid for with revenues from a cap-and-trade system that aims to cut greenhouse gas (GHG) emissions $80 \%$ below 1990 levels by 2050 . In early December 2008 - after oil prices dropped to nearly $\$ 40$ per barrel - the plan dropped provisions for a windfall profit tax on oil companies that would have been used to provide $\$ 500$ rebate checks to individuals. Reducing dependence on foreign oil takes a high-profile position in the plan.

The plan addresses issues such as domestic oil and gas drilling, strategic petroleum reserve "swaps," clean energy technology development and deployment, energy efficiency targets, green jobs, and traditional environmental protection.

\section{Selected Highlights of New Energy for America}

- An economy-wide cap-and-trade system with $100 \%$ auction of allowances and $80 \%$ reduction in GHG emissions from 1990 levels by 2050;

- A national renewable portfolio standard (RPS) of $25 \%$ by 2025 and an extension of the production tax credit for five years;

- A requirement that $30 \%$ of the federal government's electricity come from renewable sources by 2020 , up from roughly $5 \%$ in 2007 ; and that existing federal buildings increase energy efficiency by $25 \%$ within five years;

- A public-private partnership to develop five carbon capture and sequestration plants;

- A Grid Modernization Commission that issues matching grants of $25 \%$ of qualifying investments; the plan does not address other transmission policy issues;

- Priority construction of the Alaska Natural Gas Pipeline and "use it or lose it" drilling leases; and

- $\quad$ A goal to put 1 million plug-in hybrid electric vehicles (PHEVs) on the road by 2015.

\section{Selected Implementation Challenges}

One challenge in this plan will be in coordinating congressional action. Funding for many of the technology development and deployment mechanisms will depend on revenues created in the cap-and-trade auctions. However, Congress is likely to prioritize economic recovery, energy legislation, and climate legislation in that order.

Other challenges will be the specific design features of the cap and trade, and national RPS, systems. In the former, Congress will wrestle with how to define and auction allowances; in the latter, the challenge will be how to achieve regional buy-in for a national RPS. 


\section{Transition to Green (Green)}

Transition to Green, at more than 390 pages, is by far the most detailed plan. It provides three priority recommendations for each federal government agency, followed by key administrative, legislative, and budgetary policy actions for the first 100 days (between Inauguration Day and Earth Day) of the new administration. This plan focuses on restoring environmental quality more than any other plan. Four priority areas for action include: clean energy and climate change, federal budget and stimulus legislation to achieve national environmental and health goals, re-establishing the White House as a leader on clean energy and the environment, and putting the right people in the right jobs.

Summarizing this plan in one page is a challenge, but key highlights that focus mainly on clean energy are highlighted in the box below.

\section{Selected Highlights of the Transition to Green Plan}

- Work with other nations to reach a new climate treaty at the Copenhagen climate summit in 2009 that keeps further warming below $2^{\circ} \mathrm{F}$;

- Restore the Council on Environmental Quality's budget and staff (from 24 full-time employees to at least 45);

- Persuade Congress to reinstate the Office of Technology Assessment;

- Set robust efficiency standards and fully exploit existing standard setting authority (DOE);

- Establish a Federal Advisory Committee to recommend criteria for siting and operation of renewable energy generation and transmission options on public and private lands;

- Rescind Executive Orders 13211 and 13212 expediting energy projects on federal lands, and reinstate the Congressional moratorium on offshore drilling that expired on October 1, 2008; and

- Maximize light-duty fuel economy standards to $35 \mathrm{mpg}$ for 2015 and $42 \mathrm{mpg}$ for 2020.

\section{Selected Implementation Challenges}

Transition to Green is a comprehensive set of recommendations. It is uniquely organized because it focuses on administrative action by government agencies. Implementation cost is unknowable, especially in areas where greater environmental litigation, for example, is suggested. On the whole, the plan suggests a "wish list" of actions that would lead to greater environmental protection and quality, but it does not attempt to determine the economic costs or economic efficiency of implementing the changes. 


\section{A Climate Plan for the New Administration (Justinian)}

This plan is significantly different from others in that it focuses almost entirely on what the incoming administration can do to address the climate challenge without legislative concurrence. It was drafted by anonymous authors using the nom de plum, Justinian, a late era Roman emperor known for "restoration of the empire." The plan offers unique, and sometimes arcane, suggestions.

One such example is the recommendation to eliminate the Office of Information and Regulatory Affairs (OIRA) within the Office of Management and Budget. ${ }^{14}$ According to the authors, OIRA needs to facilitate rather than impede the new administration's efforts to address global warming, and the existing OIRA mandate does not allow that.

\section{Selected Highlights of the Justinian Climate Plan}

- Granting EPA the authority to regulate greenhouse gases under the Clean Air Act, and California permission to regulate them from motor vehicles;

- Reorienting and reorganizing the White House to address global warming;

- Eliminating subsidies that reward highly polluting energy resources, with advice on how to navigate the politics of subsidy removal;

- Managing more than $\mathbf{4 5 0}$ million acres of public lands to sequester carbon dioxide; and

- Exercising presidential leadership to encourage citizens to reduce GHG emissions associated with individual and household choices.

\section{Selected Implementation Challenges}

A prominent recommendation is that the EPA should set a new source performance standard (NSPS) for coal plants equivalent to that of integrated gasification combinedcycle (IGCC) technology. It does so claiming that IGCC plants produce $12 \%$ less $\mathrm{CO}_{2}$ than state-of-the-art supercritical coal units, and 30\% less than average coal plants in use today. While this claim is controversial given today's IGCC units, ${ }^{15}$ the real intent seems to be for the future capture and sequestration of carbon dioxide, which is anticipated to be more feasible on IGCC than pulverized coal plants.

The Justinian Plan also notes that the United States should follow the example of China in using "environmental dispatch" rather than economic dispatch on our power plants. In many areas of the United States, however, this is already the case because wind, solar, and other renewable sources of power have the lowest marginal costs (no fuel costs combined with the production tax credit) and are almost always the first plants dispatched.

This plan faces fewer external challenges than the other plans because it does not rely on congressional action.

\footnotetext{
${ }^{14}$ Or at least reworking Executive Order 12866, which directs OIRA to use cost-benefit analysis to review proposed regulations.

${ }^{15}$ According to MIT, IGCC plants today emit slightly more carbon dioxide than supercritical plants. MIT, The Future of Coal, 2007, Table 3.5.
} 


\section{Clean Energy 2030 (Google)}

Google's version 1.0 energy plan, written by Jeffery Greenblatt, was issued on October 1, 2008. Version 2.0, which included updates based on public comments and the demands of a rapidly deteriorating economy, came out approximately six weeks later.

Similar to the Repower America plan, it calls for a deployment of EE and RE options, and plug-in hybrid electric vehicles. A key difference, however, is that it does so over a longer time frame without the need to decommission existing plants. It also attempts to track the cost of the plan. While Clean Energy 2030 tells a specific story of how much new energy will be deployed when, it provides little discussion of the policy tools or institutional changes that could enable it. Specific targets identified in Clean Energy 2030 are noted in the text box below.

\section{Selected Highlights in the Google Energy Plan by 2030}

- A $33 \%$ reduction in electricity demand from EIA's 2030 forecast due to end-use efficiency measures;

- $380 \mathrm{GW}$ of wind power;

- $170 \mathrm{GW}$ of solar PV and $80 \mathrm{GW}$ of concentrating solar power (CSP);

- $80 \mathrm{GW}$ of geothermal;

- Plug-in hybrid electric vehicles accounting for $90 \%$ of new car sales by 2030 ;

- Accelerating turnover of the entire vehicle fleet from 19 to 13 years by 2030;

- Creation of 9 million new jobs;

- Net financial savings of $\$ 820$ million measured in undiscounted 2008 dollars; and

- A $41 \%$ reduction in national carbon dioxide emissions from today's level.

\section{Selected Implementation Challenges}

The Google plan assumes modest growth in nuclear generating capacity $(115 \mathrm{GW})$, and a complete phase-out of coal generation by 2030. It does not see CCS playing a role by then due to technical, legal, and economic barriers. By 2030, 22 million plug-in vehicles would be deployed and reportedly result in an $8 \%$ increase in electricity demand.

While many of the targets noted in Clean Energy 2030 are similar to those called for in the Repower America or Pickens Plan, the schedule to achieve them is more generous. The extra 10 years to deploy wind, PV, geothermal, CSP, and plug-in vehicles make supply-chain distortions less likely.

The Google plan is likely to attract criticism for the lack of detail in its policy prescriptions rather than the relatively aggressive targets it proposes in the long term. It provides integrated "modeling results" more than it does a prescriptive plan for how we can overcome key energy challenges. It is unclear what combination of designs in a national RPS, a carbon price, and long-term PTC would achieve the targets called for by the plan. 


\section{A Transition Plan for Securing America's Energy Future (Commerce)}

This plan identifies 13 pillar energy issues for the administration, Congress, states, and private-sector entities to address, with timelines for each issue. It calls for fundamental change in our future energy policy. It echoes many of the national security concerns raised in the SAFE plan, but focuses more on the need for traditional domestic energy, including nuclear power. Although the plan calls for expanded study of climate change, it does not call for carbon mitigation policy that might constrain fossil energy options. The plan recommends expanding the leasing program for oil shale and other frontier hydrocarbons. It also voices less confidence in government regulation and oversight, and more in market-based solutions. Many incentives are thus recommended in the form of expanded tax credits and tax depreciation.

Retired General James Jones led the development of this plan for the Chamber of Commerce. After the plan was released in November 2008, Jones was appointed to head the National Security Council in the incoming Obama administration. The new advisor has noted his desire to stay involved in energy issues that affect national security.

\section{Selected Highlights of the Chamber of Commerce Plan}

- Expanding production of domestic oil shale, oil sands, and other hydrocarbons;

- Doubling support for energy technology R\&D, including a new ARPA-E program;

- Establishing a Climate Change Adaptation Program, but no mention of support for mandatory carbon mitigation policy;

- Establishing a new tax credit for retrofitting existing coal-fired power plants;

- Extending renewable energy tax credits for eight years;

- Fostering privately owned central facilities to temporarily store spent nuclear fuel; and

- Establishing a fund to be administered by utilities to invest in CCS.

\section{Selected Implementation Challenges}

Some observers may oppose the plan because it calls for a reduction in "overly burdensome regulations" at a time when public confidence in markets is at a nadir. Others will find the lack of urgency to mitigate greenhouse gases a drawback. More than other plans, however, this one takes a comprehensive view of the role that different public and private organizations should play in our energy future, and offers timelines for action by each. 


\section{Energy Efficiency and Economic Recovery Initiative (EEI+) ${ }^{16}$}

This is the most recently issued plan of those explored in this paper, and has helped shape development of parts of the economic stimulus package. The initiative calls for a national goal of retrofitting 2 million buildings during the next two years. The plan tallies direct implementation costs of roughly $\$ 33$ billion to carry out the dozen primary recommendations. It was designed to be implemented quickly, and would largely operate under existing agencies and programs. No estimates are provided of the amount of energy that might be saved, ${ }^{17}$ or the number of new jobs that would be created.

\section{Selected Highlights of the Energy Efficiency and Economic Recovery Initiative}

- State energy efficiency grants program (\$13 billion) allocated to utilities, school districts, cooperatives, and energy service companies (ESCOs) in two tranches. The first tranche comes with no conditions, but the second would depend on state action on utility reform (decoupling) and building code requirements;

- Congress to appropriate $\$ 6$ billion in funding previously authorized in the Energy Security and Independence Act of 2007 for energy efficiency and conservation block grants. The grants would be offered to local governments, again with a second tranche of funding dependent on the level of action achieved during the first;

- A $\$ 3$ billion component to renovate schools with green attributes, along with $\$ 500$ million for workforce training; and

- $\$ 500$ million to support new and existing programs operated by DOE and EPA. The two agencies should develop guidance for states and local government to ensure efficient spending on the two grant programs noted above.

\section{Selected Implementation Challenges}

The ultimate cost of several of the recommendations is difficult to estimate because they call for tax credits or matching funds that may not be limited by ceilings. Although the recommendations to use block grants as the primary funding mechanism has advantages regarding supporting established programs at the local level, there is also the potential for disconnect between federal and state or local priorities. Finally, it is possible that energy efficiency priorities will be mischaracterized, resulting in less than optimal spending. These are risks that any quick-impact spending plans face.

\footnotetext{
${ }^{16}$ The Alliance to Save Energy, the Energy Future Coalition, and the Natural Resources Defense Council are the three nongovernment organizations (NGOs) that partnered with EEI in this plan.

${ }^{17}$ One news story, however, notes that "All told, the program might drop the country's energy consumption by half a percent each year for 20 years." It is not clear who made this estimate (see Hargreaves 2008).
} 


\section{Appendix B - List of Selected National Energy Plans}

\begin{tabular}{|c|c|c|c|}
\hline Author & $\begin{array}{l}\text { Date } \\
\text { Issued }\end{array}$ & Title & Source \\
\hline $25 \times 25$. org & Dec-08 & $\begin{array}{l}\text { Recommendations for Economic Recovery and a Clean } \\
\text { Energy Future: } 25 \times 25 \text { National Steering Committee }\end{array}$ & $\begin{array}{l}\text { http://www.25x25.org/storage/25x25/documents/Economic } \\
\text { Recovery/economic_recovery_recommendations- } \\
\text { 12_15_08.pdf }\end{array}$ \\
\hline $\begin{array}{l}\text { Al Gore / Repower } \\
\text { America }\end{array}$ & 2008 & Repower America/We can solve it.org (“Repower”) & http://www.wecansolveit.org/content/solutions \\
\hline $\begin{array}{l}\text { American Chemistry } \\
\text { Council }\end{array}$ & May-08 & $\begin{array}{l}\text { Remarks by Jack N. Gerard, President and CEO, } \\
\text { American Chemistry Council - Nuclear Energy } \\
\text { Assembly: Energizing a Low-Carbon Future Nuclear } \\
\text { Energy Institute }\end{array}$ & $\begin{array}{l}\text { http://www.americanchemistry.com/s_acc/sec_mediakits.as } \\
\text { p?CID=217\&DID=7337 }\end{array}$ \\
\hline $\begin{array}{l}\text { American Small } \\
\text { Business League }\end{array}$ & Jan-09 & $\begin{array}{l}\text { Obama Windfall Profits Tax on Oil and Gas Industry Could } \\
\text { Fund Stimulus Plan }\end{array}$ & http://www.asbl.com/showmedia.php?id=1249 \\
\hline $\begin{array}{l}\text { American Wind } \\
\text { Energy Association }\end{array}$ & 2008 & Wind Energy for New Era & http://www.newwindagenda.org/ \\
\hline Apollo Alliance & Sep-08 & $\begin{array}{l}\text { The New Apollo Program: Clean Energy, Good Jobs } \\
\text { ("Apollo") }\end{array}$ & http://apolloalliance.org/apollo-14/the-full-report/ \\
\hline Brookings Institute & 2008 & Memo to the President: Build a Secure Energy Future & $\begin{array}{l}\text { http://www.brookings.edu/papers/2008/1111_energy_secur } \\
\text { ity_memo.aspx }\end{array}$ \\
\hline Brookings Institute & Feb-09 & $\begin{array}{l}\text { Energy Discovery-Innovation Institutes: A Step toward } \\
\text { America's Energy Sustainability }\end{array}$ & \\
\hline $\begin{array}{l}\text { Business Council for } \\
\text { Sustainable Energy }\end{array}$ & Jan-09 & $\begin{array}{l}\text { Clean Energy and Energy Efficiency Program } \\
\text { Recommendations for Inclusion in } 2009 \text { Economic } \\
\text { Stimulus }\end{array}$ & http://www.bcse.org/images/pdf/bcseecrecvryrecssenfnl.pdf \\
\hline $\begin{array}{l}\text { Center for American } \\
\text { Progress }\end{array}$ & Sep-08 & $\begin{array}{l}\text { Green Recovery: A Program to Create Good Jobs and } \\
\text { Start Building a Low-Carbon Economy ("CAP") }\end{array}$ & $\begin{array}{l}\text { http://www.americanprogress.org/issues/2008/09/pdf/green } \\
\text { recovery.pdf }\end{array}$ \\
\hline $\begin{array}{l}\text { Center for American } \\
\text { Progress }\end{array}$ & Nov-07 & $\begin{array}{l}\text { Capturing the Energy Opportunity: Creating a Low-Carbon } \\
\text { Economy }\end{array}$ & $\begin{array}{l}\text { http://www.americanprogress.org/issues/2007/11/energy_c } \\
\text { hapter.html }\end{array}$ \\
\hline $\begin{array}{l}\text { Center for American } \\
\text { Progress }\end{array}$ & 2008 & $\begin{array}{l}\text { Change for America - A Progressive Blueprint for America } \\
\text { for the } 44^{\text {th }} \text { President. National Energy Council Chapters. }\end{array}$ & $\begin{array}{l}\text { http://images2.americanprogress.org/CAPAF/2008/changef } \\
\text { oramerica/WhiteHouse_04_Stern_Hayes.pdf }\end{array}$ \\
\hline $\begin{array}{l}\text { U.S. Chamber of } \\
\text { Commerce }\end{array}$ & Sep-08 & Blueprint for Securing America's Energy Future & http://www.energyxxi.org/xxi/default \\
\hline
\end{tabular}




\begin{tabular}{|c|c|c|c|}
\hline Author & $\begin{array}{l}\text { Date } \\
\text { Issued }\end{array}$ & Title & Source \\
\hline $\begin{array}{l}\text { U.S. Climate Action } \\
\text { Partnership(USCAP) }\end{array}$ & Jan-09 & $\begin{array}{l}\text { A Blueprint for Legislative Action: Consensus } \\
\text { Recommendations for U.S. Climate Protection Legislation }\end{array}$ & http://www.us-cap.org/pdf/USCAP_Blueprint.pdf \\
\hline $\begin{array}{l}\text { U.S. Conference of } \\
\text { Mayors }\end{array}$ & Dec-08 & $\begin{array}{l}\text { Mainstreet Economic Recovery: "Ready to Go" Jobs and } \\
\text { Infrastructure Projects }\end{array}$ & $\begin{array}{l}\text { http://www.usmayors.org/mainstreeteconomicrecovery/defa } \\
\text { ult.asp?Area=Energy }\end{array}$ \\
\hline $\begin{array}{l}\text { U.S. Conference of } \\
\text { Mayors }\end{array}$ & Nov-08 & Current and Potential Green Jobs in the U.S. Economy & $\begin{array}{l}\text { http://www.usmayors.org/pressreleases/uploads/GreenJob } \\
\text { sReport.pdf }\end{array}$ \\
\hline $\begin{array}{l}\text { Council on } \\
\text { Competitiveness }\end{array}$ & Feb-08 & $\begin{array}{l}\text { Progressive Dialogue I: The Energy-Competitiveness } \\
\text { Relationship }\end{array}$ & http://www.compete.org/publications/detail/407/define/ \\
\hline $\begin{array}{l}\text { Council on } \\
\text { Competitiveness }\end{array}$ & Aug-08 & $\begin{array}{l}\text { Progressive Dialogue II: Demand Drivers for Sustainable } \\
\text { Energy Solutions }\end{array}$ & http://www.compete.org/publications/detail/563/discover/ \\
\hline $\begin{array}{l}\text { Council on } \\
\text { Competitiveness }\end{array}$ & Oct-08 & 100-Day Energy Action Plan for $44^{\text {th }}$ President & $\begin{array}{l}\text { http://www.compete.org/news/entry/560/council-on- } \\
\text { competitiveness-challenges-next-president-to-execute-100- } \\
\text { day-energy-action-plan-for-america/ }\end{array}$ \\
\hline $\begin{array}{l}\text { Demand Response } \\
\text { and Smart Grid } \\
\text { Coalition }\end{array}$ & Nov-08 & $\begin{array}{l}\text { Demand Response and Smart Grid Policy } \\
\text { Recommendations for the Obama Administration and } \\
111^{\text {th }} \text { Congress }\end{array}$ & $\begin{array}{l}\text { http://www.drsgcoalition.org/policy/DRSG_Policy_Recomm } \\
\text { endations_to_Accelerate_DR_and_Smart_Grid-2008-11- } \\
\text { 24.pdf }\end{array}$ \\
\hline Dow Plan & Nov-08 & Dow's Energy Plan for America & http://news.dow.com/dow_news/pdfs/dow_energy_plan.pdf \\
\hline $\begin{array}{l}\text { Edison Electric } \\
\text { Institute, }+3 \text { NGOs }\end{array}$ & Dec-08 & Energy Efficiency and Economic Recovery Initiative & $\begin{array}{l}\text { http://www.eei.org/industry_issues/retail_services_and_deli } \\
\text { very/wise_energy_use/2008-12- } \\
\text { 19FinalEEPolicyRecommendations1947Clean4.pdf }\end{array}$ \\
\hline $\begin{array}{l}26 \text { Environmental } \\
\text { Groups }\end{array}$ & Nov-08 & $\begin{array}{l}\text { Transition to Green: Leading the way to a healthy } \\
\text { environment, a green economy, and a sustainable future }\end{array}$ & http://docs.nrdc.org/legislation/files/leg_08112401a.pdf \\
\hline $\begin{array}{l}\text { FBR Capital Markets } \\
\text { Corporation }\end{array}$ & Dec-08 & $\begin{array}{l}\text { Testimony of Kevin Brook, Senior VP of Energy Policy, Oil } \\
\text { and Alternative Energy, before the U.S. Senate } \\
\text { Committee on Energy and Natural Resources }\end{array}$ & \\
\hline Google.org & Oct-08 & $\begin{array}{l}\text { Clean Energy 2030: Google's proposal for reducing U.S. } \\
\text { dependence on fossil fuels }\end{array}$ & http://knol.google.com/k/-/-/15x31uzlqeo5n/1\# \\
\hline $\begin{array}{l}\text { Harvard: Energy } \\
\text { Technology } \\
\text { Innovation Policy }\end{array}$ & Oct-08 & Memo to the Next President: Addressing the Energy Crisis & $\begin{array}{l}\text { http://belfercenter.ksg.harvard.edu/publication } / 18590 / \mathrm{mem} \\
\text { o_to_the_next_president.html?breadcrumb }=\% 2 \mathrm{Fproject} \% 2 \\
\text { F10\%2Fenergy_technology_innovation_policy }\end{array}$ \\
\hline $\begin{array}{l}\text { Harvard: Belfer } \\
\text { Center }\end{array}$ & 2008 & $\begin{array}{l}\text { "For the Next President: Center Scholars Suggest Priority } \\
\text { Actions on Security, Climate/Energy and the Financial } \\
\text { Crisis" }\end{array}$ & $\begin{array}{l}\text { http://belfercenter.ksg.harvard.edu/publication/18600/for_th } \\
\text { e_next_president.html }\end{array}$ \\
\hline
\end{tabular}




\begin{tabular}{|c|c|c|c|}
\hline Author & $\begin{array}{c}\text { Date } \\
\text { Issued }\end{array}$ & Title & Source \\
\hline Heritage Foundation & Jun-07 & Twelve Principles to Guide U.S. Energy Policy & $\begin{array}{l}\text { http://www.heritage.org/Research/EnergyandEnvironment/ } \\
\text { bg2046.cfm }\end{array}$ \\
\hline ICLEI & Dec-08 & $\begin{array}{l}\text { Empowering Local Government Climate Action: Blueprint } \\
\text { for the New President and } 111^{\text {th }} \text { Congress }\end{array}$ & $\begin{array}{l}\text { http://www.icleiusa.org/action-center/affecting- } \\
\text { policy/Climate\%20Action\%20Blueprint.pdf }\end{array}$ \\
\hline $\begin{array}{l}\text { Independent } \\
\text { Petroleum } \\
\text { Association of } \\
\text { America (IPAA) }\end{array}$ & May-08 & Global Climate Change: Concerns and Impacts & $\begin{array}{l}\text { http://www.ipaa.org/news/docs/Climate-ConcernsImpacts- } \\
\text { May2008.pdf }\end{array}$ \\
\hline $\begin{array}{l}\text { Institute for the } \\
\text { Analysis of Global } \\
\text { Security (IAGS) }\end{array}$ & May-08 & $\begin{array}{l}\text { Rising Oil Prices, Declining National Security. Testimony } \\
\text { by Anne Korin to the House Committee on Foreign Affairs }\end{array}$ & http://www.iags.org/Korin_HFRC_052208.pdf \\
\hline James Hansen & Dec-08 & Letter to Barack and Michelle Obama & $\begin{array}{l}\text { http://www.columbia.edu/ jeh1/mailings/20081229_DearMi } \\
\text { chelleAndBarack.pdf }\end{array}$ \\
\hline James Hansen & Dec-08 & Tell Barack Obama the Truth - The Whole Truth & $\begin{array}{l}\text { http://www.columbia.edu/ jeh1/mailings/20081229_Obama } \\
\text { revised.pdf }\end{array}$ \\
\hline John McCain & Jun-08 & $\begin{array}{l}\text { Lexington Project: A Comprehensive Plan to Break } \\
\text { Dependence on Foreign Oil }\end{array}$ & John McCain \\
\hline Justinian & Nov-08 & A Climate Plan for the New Administration & http://docs.google.com/View?docid=dcqm4999_1f7h4xjgm \\
\hline $\begin{array}{l}\text { National Association } \\
\text { of State Energy } \\
\text { Officials (NASEO) }\end{array}$ & Dec-08 & $\begin{array}{l}\text { Testimony of Malcolm D. Woolf, Director of the Maryland } \\
\text { Energy Administration, before the Committee on Energy } \\
\text { and Natural Resources }\end{array}$ & \\
\hline $\begin{array}{l}\text { National } \\
\text { Commission on } \\
\text { Energy Policy }\end{array}$ & Dec-04 & Ending the Energy Stalemate & $\begin{array}{l}\text { http://www.energycommission.org/ht/a/GetDocumentAction } \\
\text { /i/1088 }\end{array}$ \\
\hline $\begin{array}{l}\text { National } \\
\text { Commission on } \\
\text { Energy Policy }\end{array}$ & Apr-07 & $\begin{array}{l}\text { Energy Commission Proposes Plan to Cut Total U.S. } \\
\text { Climate Emissions in First Year of Program }\end{array}$ & $\begin{array}{l}\text { http://www.energycommission.org/ht/display/ReleaseDetail } \\
\text { s/i/1548/pid/500 }\end{array}$ \\
\hline $\begin{array}{l}\text { National Electrical } \\
\text { Manufacturers } \\
\text { Association (NEMA) }\end{array}$ & Nov-08 & $\begin{array}{l}\text { Recommendations to President-elect Obama on Key } \\
\text { Electro-industry Issues }\end{array}$ & $\begin{array}{l}\text { http://www.nema.org/gov/upload/President- } \\
\text { Elect\%20Barack\%20Obama\%20letter-3.pdf }\end{array}$ \\
\hline $\begin{array}{l}\text { National Electrical } \\
\text { Manufacturers } \\
\text { Association (NEMA) }\end{array}$ & Dec-08 & $\begin{array}{l}\text { Recommendations to Congress on Economic and } \\
\text { Infrastructure Stimulus }\end{array}$ & $\begin{array}{l}\text { http://www.nema.org/gov/upload/Comp\%20Stimulus\%20Le } \\
\text { tter.pdf }\end{array}$ \\
\hline
\end{tabular}




\begin{tabular}{|c|c|c|c|}
\hline Author & $\begin{array}{l}\text { Date } \\
\text { Issued }\end{array}$ & Title & Source \\
\hline Obama - Biden & Nov-08 & New Energy for America Plan & $\begin{array}{l}\text { http://www.barackobama.com/pdf/factsheet_energy_speec } \\
\text { h_080308.pdf }\end{array}$ \\
\hline $\begin{array}{l}\text { Pew Center on } \\
\text { Global Climate } \\
\text { Change }\end{array}$ & Nov-08 & $\begin{array}{l}\text { "U.S. Climate Action: The Path Forward." Article by } \\
\text { Eileen Claussen and Manik Roy }\end{array}$ & http://www.pewclimate.org/op-ed/climate-action/11-14-08 \\
\hline $\begin{array}{l}\text { Pew Center on } \\
\text { Global Climate } \\
\text { Change }\end{array}$ & Jan-09 & $\begin{array}{l}\text { Congressional testimony of Eileen Claussen - USCAP } \\
\text { Recommendations for Climate Legislation }\end{array}$ & $\begin{array}{l}\text { http://www.pewclimate.org/testimony/claussen/uscap- } \\
\text { recommendations }\end{array}$ \\
\hline $\begin{array}{l}\text { Peterson Institute for } \\
\text { International } \\
\text { Economics and WRI }\end{array}$ & Feb-09 & $\begin{array}{l}\text { Policy Brief: A Green Global Recovery? Assessing US } \\
\text { Economic Stimulus and the Prospects for International } \\
\text { Coordination }\end{array}$ & http://www.wri.org/publication/green-global-recovery \\
\hline The Pickens Plan & Aug-08 & The Pickens Plan & http://www.pickensplan.com/index.php \\
\hline $\begin{array}{l}\text { Progressive Policy } \\
\text { Institute }\end{array}$ & Jan-09 & $\begin{array}{l}\text { Memos to the Next President: Putting Energy in the White } \\
\text { House, Energy Efficiency as Economic Stimulus, Making } \\
\text { America the World's Clean Car Leader, Establishing a } \\
\text { Global Environmental Organization (GEO), America's } \\
\text { Nuclear Waste and What to Do With It }\end{array}$ & $\begin{array}{l}\text { http://www.ppionline.org/ppi_ci.cfm?contentid=254879\&knl } \\
\text { gArealD=450020\&subsecid=900193 }\end{array}$ \\
\hline $\begin{array}{l}\text { Rocky Mountain } \\
\text { Institute }\end{array}$ & Jan-09 & Top Federal Energy Policy Goals & $\begin{array}{l}\text { http://www.rmi.org/images/PDFs/Energy/RMI-Top-Federal- } \\
\text { Energy-Policies.pdf }\end{array}$ \\
\hline $\begin{array}{l}\text { Securing America's } \\
\text { Future Energy }\end{array}$ & Sep-08 & $\begin{array}{l}\text { A National Strategy for Energy Security: } \\
\text { Recommendations to the Nation on Reducing U.S. Oil } \\
\text { Dependence }\end{array}$ & $\begin{array}{l}\text { http://www.secureenergy.org/site/page.php?node=353\&id= } \\
57\end{array}$ \\
\hline Senator Bingaman & $\begin{array}{l}\text { Sep- } \\
2008\end{array}$ & Bingaman Sets the Table for Next Congress & $\begin{array}{l}\text { http://energy.senate.gov/public/index.cfm?FuseAction=Pre } \\
\text { ssReleases.Detail\&PressRelease_id=aa1c420f-ec38-43ea- } \\
\text { 8c5b-3a720e3ca5ae\&Month=9\&Year=2008\&Party=0 }\end{array}$ \\
\hline $\begin{array}{l}\text { Western Governors } \\
\text { Association (WGA) }\end{array}$ & Nov-08 & Letter to President-elect Barack Obama & $\begin{array}{l}\text { http://www.westgov.org/wga/testim/obama-energy11-20- } \\
\text { 08.pdf }\end{array}$ \\
\hline $\begin{array}{l}\text { World Resource } \\
\text { Institute (WRI) and } \\
\text { the Center for } \\
\text { Strategic and } \\
\text { International Studies } \\
\text { (CSIS) }\end{array}$ & Jan-09 & Roadmap for a Secure, Low-Carbon Energy Economy & $\begin{array}{l}\text { http://www.wri.org/publication/roadmap-for-a-secure-low- } \\
\text { carbon-energy-economy }\end{array}$ \\
\hline
\end{tabular}




\section{Appendix C - Additional Selected Policy Recommendation Examples}

\begin{tabular}{|c|c|c|c|}
\hline Issue & Policy & Select Examples & $\begin{array}{l}\text { Plans with Similar } \\
\text { Recommendations }\end{array}$ \\
\hline \multirow{5}{*}{$\begin{array}{l}\text { Energy } \\
\text { (General) }\end{array}$} & $\begin{array}{l}\text { Create a New } \\
\text { Executive Office }\end{array}$ & $\begin{array}{l}\text { The president should establish a White House National Energy Council similar to the } \\
\text { National Economic Council and Domestic Policy Council (SAFE). }\end{array}$ & $\begin{array}{l}\text { SAFE; Justinian; CAP; } \\
\text { Green; Commerce }\end{array}$ \\
\hline & Reorganize OMB & $\begin{array}{l}\text { The president should significantly reduce the authority of the Office of Information } \\
\text { and Regulatory Affairs by repealing Executive Order } 12866 \text { (Justinian). }\end{array}$ & Green; Justinian \\
\hline & \multirow{3}{*}{$\begin{array}{l}\text { Increase R\&D } \\
\text { Funding }\end{array}$} & Increase energy R\&D funding levels tenfold (SAFE). & SAFE \\
\hline & & Increase energy (or clean energy) R\&D two times current levels at a minimum. & $\begin{array}{l}\text { Apollo; Commerce; } \\
\text { CAP; Green }\end{array}$ \\
\hline & & Increase energy R\&D funding three times current levels (Compete). & Compete \\
\hline \multirow{5}{*}{ Job Creation } & \multirow{5}{*}{$\begin{array}{l}\text { Promote Green } \\
\text { Workforce } \\
\text { Training } \\
\text { Initiatives }\end{array}$} & $\begin{array}{l}\text { Expand the Green Jobs Act in EISA, double federal support for national service } \\
\text { programs, and support state and local programs (Apollo). }\end{array}$ & $\begin{array}{l}\text { Apollo; SAFE; } \\
\text { Compete }\end{array}$ \\
\hline & & $\begin{array}{l}\text { The Department of Labor should assess, classify, and widely publicize the needs for } \\
\text { energy-related occupations (Compete). }\end{array}$ & Compete \\
\hline & & A "Green Vet Initiative" should provide support and jobs training for veterans (NEA). & NEA \\
\hline & & Create a public service Clean Energy Jobs Corps, modeled after Ameri-corps (CAP). & CAP; Commerce \\
\hline & & $\begin{array}{l}\text { Congress should fully fund the America COMPETES Act; and reform visa and } \\
\text { immigration policies to enhance retention of U.S.-educated graduates (Commerce). }\end{array}$ & Commerce \\
\hline \multirow{2}{*}{$\begin{array}{l}\text { Carbon } \\
\text { Emissions }\end{array}$} & $\begin{array}{l}\text { National Cap- } \\
\text { and-Trade } \\
\text { Program }\end{array}$ & $\begin{array}{l}\text { Implement a national cap-and-trade program to reduce GHG emissions } 80 \% \text { below } \\
1990 \text { levels by } 2050 \text {. Auction permits and use revenues to invest in renewables } \\
\text { (Green). }\end{array}$ & $\begin{array}{l}\text { Green; NEA; Apollo; } \\
\text { CAP }\end{array}$ \\
\hline & $\begin{array}{l}\text { Lead } \\
\text { International } \\
\text { Engagement }\end{array}$ & $\begin{array}{l}\text { The U.S. should re-engage with the U.N. Framework Convention on Climate Change } \\
\text { (UNFCC) and invigorate the Major Economies (MEM) efforts, leading major carbon- } \\
\text { emitting countries toward effective reduction strategies (NEA). }\end{array}$ & $\begin{array}{l}\text { NEA; Commerce; } \\
\text { Justinian; CAP; Green }\end{array}$ \\
\hline
\end{tabular}




\begin{tabular}{|c|c|c|c|}
\hline Issue & Policy & Select Examples & $\begin{array}{l}\text { Plans with Similar } \\
\text { Recommendations }\end{array}$ \\
\hline \multirow{12}{*}{$\begin{array}{l}\text { Fossil and } \\
\text { Nuclear } \\
\text { Energy }\end{array}$} & \multirow{4}{*}{$\begin{array}{l}\text { Expand Domestic } \\
\text { Fossil Fuel } \\
\text { Production }\end{array}$} & $\begin{array}{l}\text { Increase access to U.S. oil and natural gas reserves on the Outer Continental Shelf } \\
\text { with sharply increased and expanded environmental protections (SAFE). }\end{array}$ & SAFE; Commerce \\
\hline & & Incentivize enhanced oil recovery extraction processes on existing fields (NEA). & NEA; SAFE \\
\hline & & $\begin{array}{l}\text { Repeal Section } 526 \text { of EISA, currently preventing the government from utilizing coal- } \\
\text { to-liquids or oil shale (Commerce). }\end{array}$ & Commerce; SAFE \\
\hline & & $\begin{array}{l}\text { The president and Congress should actively support the construction of the Alaska } \\
\text { natural gas pipeline (Commerce). }\end{array}$ & $\begin{array}{l}\text { Commerce; SAFE; } \\
\text { NEA }\end{array}$ \\
\hline & $\begin{array}{l}\text { Reduce Fossil } \\
\text { Fuel Industry } \\
\text { Subsidies }\end{array}$ & $\begin{array}{l}\text { The president should create an independent commission to make recommendations } \\
\text { for eliminating subsidies for highly polluting industries; Congress should establish } \\
\text { authority for this commission similar to the past Base Closure and Realignment } \\
\text { Commission (Justinian). }{ }^{18}\end{array}$ & $\begin{array}{l}\text { Justinian; Apollo; } \\
\text { Green; CAP; Compete; } \\
\text { SAFE }\end{array}$ \\
\hline & $\begin{array}{l}\text { Strategic } \\
\text { Petroleum } \\
\text { Reserve (SPR) }\end{array}$ & $\begin{array}{l}\text { Evaluate use of the SPR, to possibly include refined products, and expand the } \\
\text { reserve to } 1 \text { billion barrels as required under EPAct (Commerce). }\end{array}$ & $\begin{array}{l}\text { Commerce; SAFE; } \\
\text { NEA }\end{array}$ \\
\hline & \multirow{4}{*}{$\begin{array}{l}\text { Advance } \\
\text { Power Plant } \\
\text { Emissions } \\
\text { Controls }\end{array}$} & $\begin{array}{l}\text { Establish an emissions performance standard for all new coal-fired facilities } \\
\text { equivalent to best available CCS technology; use federal funds to offset additional } \\
\text { costs of implementing CCS technology (CAP). }\end{array}$ & $\begin{array}{l}\text { CAP; Commerce; } \\
\text { SAFE; Green }\end{array}$ \\
\hline & & $\begin{array}{l}\text { Use the Clean Air Act to declare that global warming pollution endangers public } \\
\text { health and welfare, and to set standards for power plants, vehicles, and fuels. } \\
\text { (Green) }\end{array}$ & Justinian; Green \\
\hline & & $\begin{array}{l}\text { Congress should NOT use the Clean Air Act or the Endangered Species Act to } \\
\text { regulate carbon emissions (Commerce). }\end{array}$ & Commerce \\
\hline & & $\begin{array}{l}\text { Congress should enact a new Section } 48 \mathrm{C} \text { tax credit to retrofit existing coal-fired } \\
\text { plants and expand the clean coal investment tax credit program to stimulate } \\
\text { construction of IGCC plants (Commerce). }\end{array}$ & Commerce \\
\hline & \multirow{2}{*}{ Nuclear Energy } & $\begin{array}{l}\text { Congress should allow the private sector to manage nuclear waste, and the federal } \\
\text { government should proceed with Yucca Mountain licensing (Commerce). }\end{array}$ & $\begin{array}{l}\text { Commerce (Green } \\
\text { opposes) }\end{array}$ \\
\hline & & $\begin{array}{l}\text { Continue the licensing process for Yucca Mountain and increase funding levels for } \\
\text { loan guarantees for new nuclear generation (SAFE). }\end{array}$ & $\begin{array}{l}\text { SAFE; Commerce } \\
\text { (Green opposes) }\end{array}$ \\
\hline
\end{tabular}

${ }^{18}$ In addition to fossil fuels, Justinian includes reducing subsidies for nuclear energy and ethanol in this recommendation. 


\begin{tabular}{|c|c|c|c|}
\hline Issue & Policy & Select Examples & $\begin{array}{l}\text { Plans with Similar } \\
\text { Recommendations }\end{array}$ \\
\hline \multirow{11}{*}{$\begin{array}{l}\text { Renewable } \\
\text { Energy }\end{array}$} & Federal RPS & $\begin{array}{l}\text { Implement a federal renewable portfolio standard requiring } 10 \% \text { of electricity } \\
\text { consumed in the United States to be derived from renewable energy by } 2012 \text { (NEA). }\end{array}$ & NEA; CAP \\
\hline & \multirow{2}{*}{$\begin{array}{l}\text { Increase Multi- } \\
\text { year R\&D } \\
\text { Investments }\end{array}$} & $\begin{array}{l}\text { Create a Clean Energy Investment Corporation to manage major EERE investments, } \\
\text { in addition to supporting local communities, from cap-and-trade revenues (Apollo). }\end{array}$ & $\begin{array}{l}\text { Apollo; CAP; NEA; } \\
\text { Green }\end{array}$ \\
\hline & & $\begin{array}{l}\text { DOE should establish, and Congress should fund, a new ARPA-E program to } \\
\text { support high-risk, exploratory research with great potential for breakthroughs } \\
\text { (Commerce). }\end{array}$ & $\begin{array}{l}\text { Commerce (SAFE } \\
\text { cautions) }\end{array}$ \\
\hline & \multirow{8}{*}{$\begin{array}{l}\text { Accelerate } \\
\text { Deployment of } \\
\text { RE Technologies }\end{array}$} & $\begin{array}{l}\text { Create a } \$ 200 \text { billion National Clean Energy Bank to provide debt financing and } \\
\text { drive private investment in EERE technologies and infrastructure (Compete). }\end{array}$ & $\begin{array}{l}\text { Compete; Apollo; } \\
\text { Commerce; CAP }\end{array}$ \\
\hline & & $\begin{array}{l}\text { DOE should spend } \$ 250 \text { million funding public-private partnerships to create } \\
\text { regional R\&D test-beds and commercial pilot projects (Compete). }\end{array}$ & Compete \\
\hline & & $\begin{array}{l}\text { Expand EISA programs aimed at biofuels infrastructure, such as pilot grant } \\
\text { programs to invest in fuel-distribution corridors (CAP). }\end{array}$ & CAP \\
\hline & & $\begin{array}{l}\text { Expand Small Business Innovation and Research (SBIR) Programs to provide } \\
\text { mezzanine financing for start-up companies (Compete). }\end{array}$ & Compete \\
\hline & & $\begin{array}{l}\text { Approve longer-term renewable energy tax credits, such as a 10-year extension of } \\
\text { the production tax credit (PTC) and investment tax credit (ITC) (Apollo). }\end{array}$ & $\begin{array}{l}\text { Apollo; NEA; SAFE; } \\
\text { Commerce }\end{array}$ \\
\hline & & $\begin{array}{l}\text { Treasury should request that Congress make the renewable production tax credit } \\
\text { (PTC) and the solar investment tax credits (ITC) refundable (Green). }\end{array}$ & Green \\
\hline & & $\begin{array}{l}\text { Congress should extend the Clean Renewable Energy Bond program to enable } \\
\text { public power systems and electric cooperatives to seek alternative-financing } \\
\text { mechanisms for projects ineligible for production tax credits (Commerce). }\end{array}$ & $\begin{array}{l}\text { Commerce; Green; } \\
\text { CAP }\end{array}$ \\
\hline & & $\begin{array}{l}\text { FERC should set national interconnection standards for a } 21 \text { st century interoperable } \\
\text { grid and transmission system (Compete). }\end{array}$ & Compete; Justinian \\
\hline
\end{tabular}




\begin{tabular}{|c|c|c|c|}
\hline Issue & Policy & Select Examples & $\begin{array}{l}\text { Plans with Similar } \\
\text { Recommendations }\end{array}$ \\
\hline \multirow{12}{*}{$\begin{array}{l}\text { Energy } \\
\text { Efficiency }\end{array}$} & \multirow{5}{*}{ Buildings } & $\begin{array}{l}\text { DOE should rapidly promulgate new appliance standards as required by both } \\
\text { EPAct2005 and EISA2007 (Commerce). }\end{array}$ & $\begin{array}{l}\text { Commerce; Obama; } \\
\text { CAP; Justinian; Green }\end{array}$ \\
\hline & & $\begin{array}{l}\text { Congress should clarify DOE's authority on setting multiple performance standards } \\
\text { for appliances and efficiency equipment products }(\mathrm{EEI}+) \text {. }\end{array}$ & EEI+ \\
\hline & & $\begin{array}{l}\text { Federally prioritize and support decoupling utilities so that shareholder profit is based } \\
\text { on reliability and performance as opposed to total energy production (NEA). }\end{array}$ & $\begin{array}{l}\text { NEA; Apollo; Green; } \\
\text { CAP }\end{array}$ \\
\hline & & $\begin{array}{l}\text { Congress should provide } \$ 6 \text { billion to local governments for the Energy Efficiency } \\
\text { and Conservation Block Grant Program authorized by EISA; distribution should be } \\
\text { tiered: } \$ 2 \text { billion without conditions, and } \$ 4 \text { billion contingent on successes (EEI+). }\end{array}$ & $\mathrm{EEI}+; \mathrm{CAP}$ \\
\hline & & $\begin{array}{l}\text { Congress should increase funding for the Weatherization Assistance Program to } \$ 1 \\
\text { billion in } 2009 \text { and } \$ 1.4 \text { billion in } 2010(\mathrm{EEI}+) \text {. }\end{array}$ & EEI+; NEA; CAP \\
\hline & \multirow{7}{*}{ Vehicles } & $\begin{array}{l}\text { Advanced battery R\&D should become a top national priority, funded with at least } \\
\$ 500 \text { million per year (SAFE). }\end{array}$ & SAFE; Commerce \\
\hline & & $\begin{array}{l}\text { Extend and modify federal subsidies for energy-efficient vehicles; half of all cars } \\
\text { purchased after } 2012 \text { by the federal government should be hybrid or electric (NEA). }\end{array}$ & $\begin{array}{l}\text { NEA; SAFE; Apollo; } \\
\text { Commerce }\end{array}$ \\
\hline & & Improve fuel-economy $4 \%$ annually after the $35 \mathrm{mpg} 2020$ target is reached (SAFE). & SAFE; NEA \\
\hline & & Eliminate tariffs on imported ethanol over a period of three years (SAFE). & SAFE; Commerce \\
\hline & & $\begin{array}{l}\text { Implement a "Health Care for Hybrids" plan to reduce legacy costs in the auto } \\
\text { industry, in return for investment and production of more efficient vehicles (CAP). }\end{array}$ & CAP \\
\hline & & $\begin{array}{l}\text { Accelerate the turnover of older vehicles through feebates, offering incentives for } \\
\text { efficient vehicles and vouchers or cash for old vehicles (Google). }\end{array}$ & Google \\
\hline & & $\begin{array}{l}\text { Congress should make the Volumetric Ethanol Excise Tax Credit (VEETC) a } \\
\text { variable credit based on oil prices (CAP). }\end{array}$ & CAP; Commerce \\
\hline \multirow{3}{*}{$\begin{array}{c}\text { Grid } \\
\text { Infrastructure }\end{array}$} & \multirow{2}{*}{$\begin{array}{l}\text { Advance } \\
\text { Smart Grid }\end{array}$} & The Smart Grid Investment Matching Grant Program should be expanded (CAP). & CAP; Commerce; NEA \\
\hline & & $\begin{array}{l}\text { Direct states to implement time-of-day pricing for electricity and grant FERC } \\
\text { authority to backstop an implementation timeline (SAFE). }\end{array}$ & SAFE \\
\hline & $\begin{array}{l}\text { Expand } \\
\text { Transmission } \\
\text { Capacity }\end{array}$ & $\begin{array}{l}\text { FERC should simplify the siting of transmission facilities after being given the same } \\
\text { authority as Section } 7 \text { under the National Gas Act; DOE should become the lead } \\
\text { agency to coordinate permits for interstate transmission after modification of Section } \\
216(\mathrm{~h}) \text { of the Federal Power Act (Commerce). }\end{array}$ & Commerce \\
\hline
\end{tabular}




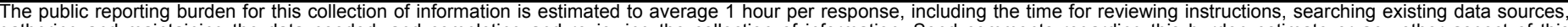

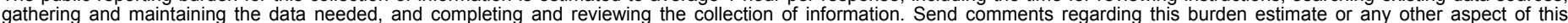

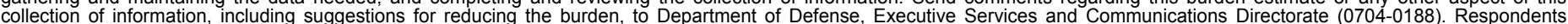

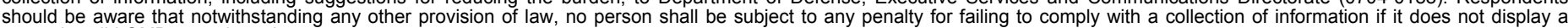

should be aware that notwithstanding

PLEASE DO NOT RETURN YOUR FORM TO THE ABOVE ORGANIZATION.

\begin{tabular}{l|l|l|l} 
1. REPORT DATE (DD-MM-YYYY) & 2. REPORT TYPE & 3. DATES COVERED (FrOm - TO)
\end{tabular} March 2009

Technical Report

4. TITLE AND SUBTITLE

A Comparative Review of a Dozen National Energy Plans: Focus on Renewable and Efficient Energy 5a. CONTRACT NUMBER

DE-AC36-08-GO28308

5b. GRANT NUMBER

5c. PROGRAM ELEMENT NUMBER

5d. PROJECT NUMBER

NREL/TP-6A2-45046

5e. TASK NUMBER

SA07.9C50

5f. WORK UNIT NUMBER
7. PERFORMING ORGANIZATION NAME(S) AND ADDRESS(ES)

National Renewable Energy Laboratory

1617 Cole Blvd.

Golden, CO 80401-3393
8. PERFORMING ORGANIZATION REPORT NUMBER

NREL/TP-6A2-45046

9. SPONSORING/MONITORING AGENCY NAME(S) AND ADDRESS(ES)

10. SPONSOR/MONITOR'S ACRONYM(S) NREL

11. SPONSORING/MONITORING AGENCY REPORT NUMBER

12. DISTRIBUTION AVAILABILITY STATEMENT

National Technical Information Service

U.S. Department of Commerce

5285 Port Royal Road

Springfield, VA 22161

13. SUPPLEMENTARY NOTES

14. ABSTRACT (Maximum 200 Words)

Dozens of groups have submitted energy, environmental, and economic recovery plans for consideration by the Obama administration and the 111th Congress. This report provides a comparative analysis of 12 national proposals, focusing especially on energy efficiency (EE) and renewable energy (RE) market and policy issues.

\section{SUBJECT TERMS}

NREL; energy plans; energy; economic recovery; environmental; energy efficiency; renewable energy; Repower America (The Gore Plan); Pickens Plan; The New Apollo Program; A National Strategy for Energy Security; Green Recovery; A 100-Day Energy Action Plan; New Energy for America; Transition to Green; A Climate Plan for the New Administration; Clean Energy 2030 (Version 2.0); A Transition Plan for Securing America's Energy Future; Energy Efficiency and Economic Recovery Initiative

\begin{tabular}{|l|l|l|l|l}
\hline \multicolumn{2}{|l|}{ 16. SECURITY CLASSIFICATION OF: } & $\begin{array}{c}\text { 17. LIMITATION } \\
\text { OF ABSTRACT }\end{array}$ & $\begin{array}{c}\text { 18. } \\
\text { NUMBER } \\
\text { OF PAGES }\end{array}$ \\
\begin{tabular}{|l|l} 
a. REPORT \\
Unclassified
\end{tabular} & $\begin{array}{l}\text { b. ABSTRACT } \\
\text { Unclassified }\end{array}$ & $\begin{array}{l}\text { c. THIS PAGE } \\
\text { Unclassified }\end{array}$ & $\begin{array}{c}\text { UL } \\
\end{array}$ &
\end{tabular}

19a. NAME OF RESPONSIBLE PERSON

19b. TELEPHONE NUMBER (Include area code) 